\title{
III. Ahmed'in Kızı Saliha Sultan ve Vakıfları (1127-1192/1715-1778)
}

\section{Ahmed III's Daughter Saliha Sultan and Her Foundations (1127-1192/1715-1778)}

\author{
Mustafa Güler* (1), Rahime Özdamar* [1]
}

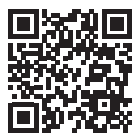

"Prof. Dr., Afyon Kocatepe Üniversitesi, Fen Edebiyat Fakültesi, Tarih Bölümü, Afyonkarahisar, Türkiye

*A Arş. Gör., Afyon Kocatepe Üniversitesi, Fen Edebiyat Fakültesi, Tarih Bölümü, Afyonkarahisar, Türkiye

ORCID: M.G. 0000-0003-2811-6403; R.Ö. 0000-0001-5117-7613

Sorumlu yazar/Corresponding author: Rahime Özdamar,

Afyon Kocatepe Üniversitesi, Fen Edebiyat Fakültesi, Tarih Bölümü, Afyonkarahisar, Türkiye E-posta/E-mail: rozdamar@aku.edu.tr

Başvuru/Submitted: 15.07.2021 Revizyon Talebi/Revision Requested: 15.09.2021

Son Revizyon/Last Revision Received: 05.10.2021

Kabul/Accepted: 17.10 .2021

\section{Atıf/Citation:}

Guler, Mustafa ve Ozdamar, Rahime.

"III. Ahmed'in Kızı Saliha Sultan ve Vakıfları (1127-1192/1715-1778)." Tarih Dergisi - Turkish Journal of History, 75 (2021): 117-158. https://doi.org/10.26650/iutd.972053
Öz

Osmanlı saltanat geleneğinde padişah kızları onlu yaşlara geldiklerinde zengin temlik veya has tahsisleri ile taltif edilmişlerdir. Nişan veya evlilik çağına geldiklerinde gösterişli törenlerle genelde maddi bakımdan zengin sayılabilecek paşalarla evlendirilmişlerdir. Saliha Sultan on üç yaşında ilk evliliğini yapmıştır. İlk evliliğinden yaklaşık bir yıl sonra çocuğu doğan Saliha Sultan 1731 yılında Mustafa Paşa'nın vefatı ile birinci kez dul kalmıştır. Bu tarihten vefatına kadar toplam beş evlilik yapmıştır.

Bu çalışmada dönemin kronikleri ile arşiv kaynaklarından yola çıkılarak Saliha Sultan'ın hayat hikâyesi ile 1738-1778 yılları arasında kurduğu vakıflarının günümüze uzanan serüveni ele alınmıştır.

Anahtar sözcükler: Saliha Sultan, Mütevelli, Akar, Hayrat, Evlatlık Vakıf

\section{ABSTRACT}

In the Ottoman sultanate tradition, the sultan's daughters were generally rewarded with important assignments or special allocations when they reached the age of ten. When they reached the age of engagement or marriage, they were most often married to pashas who could be considered wealthy, usually in ostentatious ceremonies. Saliha Sultan married for the first time at the age of 13 . She had a child about a year after her marriage and was widowed for the first time in 1731 with the death of Mustafa Pasha. From this date until his death, he had a total of five marriages.

In this study, the life story of Saliha Sultan and the history of the foundations she established between 1738-1778, still extant today, are discussed based on information found in the chronicles and archive sources of the period.

Keywords: Saliha Sultan, Foundation Manager, Source of Income of the Foundation, Zurri Foundation 


\section{Extended Abstract}

In this study, the life story of Saliha Sultan, daughter of Sultan Ahmed III, and the history of the foundations that she established between 1738-1778 are discussed based on the information found in the chronicles and archive sources of the period. For this purpose, the information in the chronicles and archive documents related to the subject have been translated and interpreted. Moreover, instead of evaluating the text of the foundation; a system based on the management of the foundation, following its sources of income and charitable benefits was followed.

In the Ottoman Empire, the daughters of the Sultans had a considerable amount of property thanks to the land income given to them as property, the mahr and inheritance they obtained from their marriage, and their commercial activities.

Their fathers, brothers, and sisters, who were also sultans when they were married or widowed, were rarely honored by later sultans who were close relatives. The mahr inherited from their spouses, pashas was the basis of their wealth as widows, and it was supplemented through inheritance or donation.

Saliha Sultan was first married at the age of 13 with 10000 gold mahr to Sari Mustafa Pasha in 1728. She was widowed for nine years after the death of her first husband, until she married a second time to Belgrade Guard Abdipashazade Ali Pasha in 1740. Later, she married a third time in 1747, after being a widow for the second time. She wed the Rumeli Governor Yahya Pasha, son of Eyüp Mosque's Imam Mustafa Efendi; however, this marriage is not mentioned in the published sources, and is only indirectly described in the chronicles of the period.

Saliha Sultan lived as a widow for three years after the death of Yahya Pasha and then of her brother Ahmed III. Upon Mustafa's accession to the throne, she married the Grand Vizier Ragip Pasha on March 31, 1758 at his request. She was widowed again after Ragıp Pasha's death in 1763, Saliha Sultan made her last marriage to Kaptan-1 Derya Mehmed Pasha in 1764.

As you can see, Saliha Sultan's marriage journey, which began at the age of 13, ended when she was 56 years old with the death of her last husband, Mehmed Pasha. It is seen that almost all of these marriages were made by the sultans of the period in line with the marriage policies of the sultan's daughters.

An important point to be mentioned in considering the marriages of Saliha Sultan is that the gifts or cash money, customarily given to the Sultan, personally or institutionally, on the marriage decision of the sultans or grand viziers has been announced, could be used in palace 
expenditures. In this way, the marriage of Saliha Sultan to Kaptanıderya Mehmed Pasha was made with the encouragement of Sultan Mustafa III.

After the death of Saliha Sultan in 1778, 25.386,5 kuruş 44 money was obtained from her opposition and a deficit of 59 kuruş was found when the expenses were calculated as 25.446 kuruş.

The mukataa found on the Saliha Sultan were determined as follows: Aclun and Leccun 16.300 kurush, Biga 1.897.980 akçe, Cretan olive oil and soap 20.130 kuruş, Karahisar-i Şarki 3.800.700 akçe, a garden in Fatih Emir Buhari 50 kuruş, from Tobacco Customs 960 kuruş, and 11 kuruş per month from 40 coins per day at the inn where a picnic fair was set up on the Peloponnese. After the determination was made, these businesses, the accounts of which were detailed, were taken into custody to be sold to her suitor or one of the members of the dynasty as they were not the property of Saliha Sultan.

Saliha Sultan registered seven foundation certificates between 1738-1776. The first of these foundations is dated 1738 and remains in effect. In the following dates, she had additional foundation charters arranged by adding akar to the first charter thereby, changing the charitable condition or adding new charitable conditions. The last endowment registered in her name in the General Directorate of Foundations was dated February 25, 1778, and two of the akars in the earlier charter dated March 12, 1776 are not present. In addition, control of the spending of the revenue obtained in this foundation was left entirely to Saliha Sultan and her children.

Although there are no foundations devoted to books in Saliha Sultan's endowments, the foundation seals on the books she donated to the Hekimoğlu Ali Pasha Library reveal that she donated books to this library.

In this study, the transcription and analysis of the foundation will not be done, but the subject is discussed with an approach that reveals the management of the foundation, its akars and charitable conditions, and the changes that have occurred in these fields from time of the Ottoman Empire to the present day. In terms of the management of a particular foundation, managers have been identified from the time of Saliha Sultan until 2021. However, it has not been determined whether the current trustee of the foundation is a descendant of Saliha Sultan.

The funds of the foundation changed both during Saliha Sultan's life and after her death. In this respect, cadastral or ownership studies were carried out on the real estate in Beykoz Göksu. It was noted that the nature of the lands had changed to a large extent, especially in the second half of the 19th century. Likewise, although Küçükçekmece and its surrounding streams, as they are called in the charter, were preserved until the end of the Ottoman Empire, 
all of these mites were abandoned by the foundation due to the intense construction in the region during the Republic of Turkey period. Further studies could be focused on restoring the mites in Küçükçekmece and its surroundings.

The charity conditions applicable to the foundation were continued in the first years of the Republic. However, because the revenues of the foundation have changed hands to a large extent and the mosque services counted in the charter are fulfilled by the Presidency of Religious Affairs, the original charity conditions cannot be fulfilled. 


\section{Giriş}

Osmanlı hanedanının kadın mensupları içinde haklarında biyografik çalışma yapılan ilk grup şüphesiz padişahların eşleri olan kadın efendiler ile hasekiler ve valide sultanlardır ${ }^{1}$. Özellikle valide sultanların, oğullarının saltanatları dönemindeki icraatları, hayat hikâyeleri ve hayır faaliyetleri araştırmacılara yeterli malzeme sunmaktadır. Padişahların kızları ise ${ }^{2}$ bu çalışmada olduğu gibi daha çok evlilikleri, vakıfları ve ticari faaliyetleri ile kaynaklara yansımışlardır.

Bu çalışmaya konu olan Saliha Sultan, Osmanlı hanedan mensupları içinde en fazla çocuğa sahip sultanlardan biri olan III. Ahmed'in kızıdır. 1703-1730 yılları arasında padişahlık yapan ve Sultan IV. Mehmed'in ikinci oğlu olan Sultan Ahmed'in hayatta kalıp evlilik çağına gelen kızları; kendisi, I. Mahmud, III. Osman, III. Mustafa ve I. Abdülhamid dönemlerinde mutat üzere vezirlerle evlendirilmişlerdir.

Padişahların kızları siyasi gerekçelerle kimi zaman küçük yaşlarda iken vezirlere nişanlanmışlarsa da tahta geçme teamülünün dışında olduklarından genelde rahat bir hayat sürmüşlerdir. Evli veya dul yaşadıkları dönemlerde padişah babaları, kardeşleri nadiren de yakın akrabaları olan sonraki padişahlar tarafından taltif edilmişlerdir. Eşleri olan paşalardan intikal eden mehir, miras veya bağış yoluyla da zenginleşmişlerdir ${ }^{3}$. Temlik veya miras olarak elde ettikleri mal varlıklarını genelde dönemin şartları icabı vakıflar kurarak ve mukataa işletmeciliği yaparak değerlendirmişlerdir. Çelebi Sultan Mehmed döneminden itibaren başlayan bu gelenek, büyük oranda çalışmamızın konusu olan Saliha Sultan'ın yaşadığı XVIII. asır hatta XIX. asrın sonlarına kadar canlı bir şekilde devam etmiştir.

Saliha Sultan hanedan mensuplarının genel hayat süreleri dikkate alındığında uzun denilebilecek bir ömür yaşamıştır. Bu süreçte babasından sonra iki amcaoğlu (I. Mahmud, II. Osman) ve iki kardeşi (III. Mustafa, I. Abdülhamid) padişahlık yapmış ve Saliha Sultan beş paşa ile evlenmiştir. Bu iki belirgin hususa bir de kendinden evvel vefat eden kız kardeşlerinin

1 Valide Sultanlar hakkında yapılan bazı çalışmalar için bkz. Ali Akyıldız, Haremin Padişahı Valide Sultan Harem 'de Hayat ve Teşkilat, Timaş Yayınları, İstanbul 2017; Betül İpşirli Argıt, Rabia Gülnuş Emetullah Sultan (1640-1715), Kitap Yayınları, İstanbul 2014; Erhan Afyoncu-Uğur Demir, Turhan Sultan, Yeditepe Yayınevi, İstanbul 2015; Arzu Terzi, Bezmialem Valide Sultan, Timaş Yayınları, İstanbul 2018. Kadın efendilerle ilgili yapılan bir çalışma için bkz. Abdullah Çakmak, “18 Yüzyılda Hayırsever Bir Padişah Kadını Vuslat Kadın’ın Medine ve İstanbul Vakıfları”, Vakıflar Dergisi, sayı 52, İstanbul 2019, s. 75-92.

2 Bu konu ile alakalı bazı çalışmalar için bkz. Ali Akyıldız, Mümin ve Müsrif Bir Padişah Kızı: Refia Sultan, Kapı Yayınları, İstanbul 2015; Serap Sunay, “Tanzimat'ın İlk Saray Dügünü: Sultan II. Mahmud'un Kız1 Atiyye Sultan'ın Ahmed Fethi Paşa ile Evlenmesi”, Belleten, LXXVII/278 (Nisan 2013), s. 119-154; Zübeyde Güneş Yağcı - Mustafa Akkaya, III. Murad ve Safiye Sultan'ın Kızları Ayşe Sultan, Berikan Yayınları, Ankara 2018; Eylül Aykan - Zübeyde Güneş Yağcı, "XVIII. Yüzyılda Sultanların Boğaz Yaşamına Katkıları: Büyük Esma Sultan”, Geçmişten Günümüze Şehir ve Kadın, I, ed. Osman Köse, Samsun 2016, s. 697-710.

3 İslam hukukunda mülk edinme yolları için bkz. Münir Kaya, "Fıkhî Açıdan Aile İçerisinde Yapılan Mülkiyet Nakilleri ve Aile Vakfıyla İlişkisi”, Afyon Kocatepe Üniversitesi İslami İlimler Fakültesi Dergisi, III/1 (Haziran 2020), 53-93. 
mallarından miras ve vasiyet yolu ile iktisap ettikleri mülkler eklendiğinde mühim bir mal varlığının olacağı aşikârdır.

Bu çalışmada ilk olarak dönemin kronikleri ve telif çalışmalardan yararlanılarak Saliha Sultan'ın doğumu, çocukluğu, eğitimi ve evlilikleri ele alınmıştır. Devamında arşiv belgeleri taranarak vakıfları, vakıflarının yönetimi, kurucunun vefatından sonraki serancamı ve nihayet günümüze uzanan süreçteki ahvali ortaya konulmuştur. Bu yönü ile çalışma bundan sonraki yapılacak vakıf mülklerinin takibi noktasında örnek teşkil edebilecek bir mahiyet arz etmektedir.

\section{Doğumu ve Çocukluğu}

Osmanlı Devleti'nde hanedanın veraset sisteminin netleşmesi sonrasında doğumlar ayrı bir öneme sahip olmuştur. İlerleyen dönemlerde saltanat çekişmeleri, şehzadelerin öldürülmeleri nihayet I. Ahmed döneminden sonra sadece padişahların çocuk sahibi olması uygulamasının başlamasıyla eskiye nazaran her doğum daha önemli hale gelmiştir. $\mathrm{Bu}$ minvalde mutad doğumlarda ve özellikle uzun aralıklar sonunda meydana gelen doğumlarda dikkate değer kutlamalar yapılmıştır. Vilâdet-i Hümâyûn denilen kutlamalarda ${ }^{4}$ başta padişah olmak üzere, varsa valide sultan ve hanedanın diğer müntesipleri gösterişli sayılabilecek hazırlıklar yapmışlardır. Sultan III. Ahmed'in tahta geçtiği 1703 tarihinden itibaren, 1730 tarihine kadar çok sayıda çocuğu olduğundan ilk doğumlardan sonraki erkek ve kız çocukların doğumları normal törenlerle karşılanmış olmalıdır5. Saliha Sultan, III. Ahmed'in saltanatının ortalarında doğduğundan velâdetindeki kutlamalar sıradan kabul edilmelidir. Saliha Sultan'ın 1127 yılı Rebiyülahir ayının ilk günlerinde (1715 Nisan başı) doğmuş olduğu kuvvetle muhtemeldir ${ }^{6}$. Bu doğum öncesinde Sultan Ahmed İstanbul' dan çıkıp Edirne'ye gitmek üzere Demirtaş Sahrasına gelmiştir ${ }^{7}$. Kendisine Saliha Sultan’ın doğumunu Sadrazam Damad Silahtar Ali Paşa şu şekilde haber vermiştir'.

4 Konuya dair örnek çalışmalar için bkz. Çağatay Uluçay, "İstanbul'da XVIII. ve XIX. Asırlarda Sultanların Doğumlarında Yapılan Törenler ve Şenliklere Dair”, İstanbul Enstitüsü Mecmuası, sayı 4, İstanbul 1958, s. 201-204; Mehmet Arslan, Osmanlı Saray Dügünleri ve Şenlikleri 6-7, Sarayburnu Kitaplı̆̆ı, İstanbul 2011, s. 17-18; Mehmet Arslan, "Osmanlı Döneminde Padişah Çocuklarının Doğumları Münasebetiyle Yapılan Şenlikler ve Vilâdet-nâme-i Hadîce Sultan”, Osmanlı Edebiyat-Tarih-Kültür Makaleleri, Kitabevi, İstanbul 2000, s. 493-494; Serap Sunay, “Bir Sultan İki Merasim: Saliha Sultan'ın Doğumu ve Dügünü”, Türk Kültürü Incelemeleri Dergisi, XXI/44 (İstanbul 2020), 140-144; Çağatay Uluçay, Harem II, 3. Bask1, Türk Tarih Kurumu Basımevi, Ankara 1992, s. 70-74.

5 III. Ahmed'in ilk kız çocuğu Fatma Sultan'ın doğum törenleri için bkz. Juliette Dumas, "Duhterciğimiz Dünyaya Geldi. III. Ahmed'in ilk Kız Çocuğu Fatma Sultan Doğumu Şerefine Düzenlenen Şenlikler”, Toplumsal Tarih, sayı 198 (Haziran 2010), s. 22-28.

6 Mehmed Süreyya, Saliha Sultan'ın doğumunu 15 Rebiyülevvel 1127 (21 Mart 1715) olarak vermektedir. Mehmed Süreyya, Sicill-i Osmânî Yahud Tezkire-i Meşahir-i Osmaniyye, I, haz. Ali Aktan vd., Sebil Yayınları, İstanbul 1995, s. 45; Necdet Sakaoğlu da aynı tarihi ancak miladi olarak 21 Mart 1715 şeklinde zikretmektedir, Necdet Sakaoğlu, Bu Mülkün Kadın Sultanları, Alfa Yayınları, İstanbul 2015, s. 435.

7 Mehmed Râşid, Tarih-i Râş̧id, IV, İstanbul 1282, s. 42.

8 Sarayda vuku bulan doğumlar genelde valide sultan tarafından padişaha bildirilmekteyken (Ali Akyıldız, Haremin Padişahı Valide Sultan Harem'de Hayat ve Teşkilat, Timaş Yayınları, İstanbul 2017, s. 226-22) bu doğumda sefer yolunda olunması sebebiyle haberi sadrazam vermiş olmalıdır. 
Kadem bastı vücuda Saliha Sultân sa âdetle,

Dil nişini gibi bir târîh-i fakîrâne arz olunup zımnında tâb-ı gostâh

Her ayıb ki Sultân be-pesended hünerest.

Haberin Sultan'a ulaştırılması sonrasında Sadrazam 30 altın avâtıf-ı şahane almıştır9.

Dönemin vakanüvisi Râşid, doğum kaydını düşerken Saliha Sultan'ın annesinden bahsetmemiştir. Saliha Sultan'ın annesi ile alakalı kroniklerde bir bilgi bulunmazken, ikinci evliliği esnasında Damad Ali Paşa tarafından Saliha Sultan'ın annesine hediye takdimi kaydedilmiş ancak isim zikredilmemiştir ${ }^{10}$. Saliha Sultan'ın annesinin isminin zikredildiği ilk vesika 1178/1764 yazında saray hanımlarına tahsis edilen kar ve buz tahsisatına dair olup burada ismi Hatem Kadın ${ }^{11}$ şeklinde kaydedilmiştir ${ }^{12}$. Saliha Sultan tarafından 1190/1776 tarihinde tesis edilen vakfiyede annesinin adının Hacce Hatun olduğu görülmektedir ${ }^{13}$. Saliha Sultan'ın 1190/1776'da bu şartı ekletmesinden annesinin yakın bir zamanda vefat ettiği sonucuna varılabilir. Bu durumda annesinin gerçek isminin Hatem Kadın olduğu ve vakfiyenin tanzim edilmesinden önce Hacce isminin hacca gitmesinden dolayı verildiği düşünülebilir. Ancak hanedan mensubu bir hanımın hacca gitmesi problemi göze alındığında bu ihtimal pek mümkün görünmemektedir. Bu durumda Hatem Kadın'ın hacca vekil göndermiş olabileceği ihtimalini yakın buluyoruz.

\section{Yetişmesi, Evlilikleri ve Çocukları}

Saliha Sultan, babasının saltanatında çocukluk dönemini Topkapı Sarayı'nda annesi ile geçirmiş, zaman zaman da Edirne'ye gidip-gelmiş olmalıdır. 1718 sonrasında ise dönemin hanedan geleneklerine uygun olarak Sâdâbad ve Beşiktaş Kasırları'nda kalmıştır. Buna dair Hammer, İbrahim Paşa'nın Beşiktaş Kasrı'nda 1721 yılı Nisan-Mayıs aylarında yapılan lale ve kandil şenliğine Sultan III. Ahmed ile birlikte oğulları Süleyman, Mehmed, Mustafa ve Bayezid ve kızları Ümmügülsüm, Hadice, Âtike, Ayşe, Saliha, Rabia ve Zeyneb; Saliha Sultan'ın annesi Hatem Kadın ile diğer kadın efendilerin katıldığını belirtmektedir ${ }^{14}$.

Saliha Sultan'ın eğitimi, okuma-yazma çağına geldiğinde bed-i besmele merasimi ile başlamıştır. Saliha Sultan ve temyîz çağına gelen diğer kız kardeşlerinin eğitimi ile bizzat

9 Râşid, IV, s. 43.

10 BOA, TSMA.D, 10364/1-1.

11 Necdet Sakaoğlu, Saliha Sultan'ın annesinin Hatem Kadın olduğunu ve ikiz doğduklarını, ikizi Şehzade Selim'in 3 yaşında vefat ettiğini yazmaktadır. Hatem Kadın'ın mezarı Eyüp Sultan Haziresindedir. Sakaoğlu, a.g.e., s. 420.

12 BOA, AE.SMST.III, 329/26537.

13 VGMA, 741, s. 251; Alderson bu ismi Ayşe Kadın'ın diğer adları olarak ve Hace Hatun şeklinde zikrederken ölüm tarihini vermemektedir. A. D. Alderson, Osmanlı Hanedanının Yapısı, Türkçesi Şefaettin Severcan, İz Yayınc1lı, İstanbul 1998, s. 270.

14 Joseph Freiherr Von Hammer-Purgstall, Büyük Osmanlı Tarihi, XIV, yay. haz. Erol Kılıç - Mümin Çevik, Üçdal Neşriyat, İstanbul 1994, s. 43-44. 
babaları Sultan III. Ahmed ilgilenmiş olmalıdır. Saliha Sultan'ın temel okuma, yazma, Kur'an okuma, tecvid ve temel dini bilgiler öğretiminin ardından el yazıları ve ifadelerinden, hüsn-i hat ve inşa dersi aldığı anlaşılmaktadır. Bu minvalde amcasının oğlu I. Mahmud'un cülusu sebebiyle gönderdiği tebriknâme ve mektuplar ${ }^{15}$, onun yazı sanatı ve inşa eğitimi aldığı ayrıca dini literatüre hâkim olduğu hakkında ciddi ipuçları sunmaktadır ${ }^{16}$.

Evlilik dönemine gelinceye kadar kendinden büyük olan ablaları ve özellikle de dönemin Sadrazamı İbrahim Paşa'nın eşi Fatma Sultan ile teşrik-i mesaide bulunmuştur. Osmanlı'da hanedan kızlarının evlilik teamülleri gereğince, 1728 yılı başlarında Saliha Sultan ve o sırada evlilik veya nişan çağında olan diğer sultanların uygun paşalar ile evlendirilmesi gündeme gelmiştir. Bu minvalde anılan tarihte 13 yaşında olan Saliha Sultan'ın yaptığı beş evlilikten birincisinin süreci başlamıştır. Saliha Sultan'ın ilk evliliği olması hasebiyle damat seçimi, nişan ve düğün merasimleri dönemin vakanüvisi Râşid Efendi tarafından detaylı olarak anlatılmıştır. Sultan III. Ahmed, 1728 yılı bahar aylarında bâliğ olmuş ve temyîz çağında olan üç kızından en büyüğü olan Saliha Sultan ile evlenmesi münasip olabilecek paşa ile alakalı Sadrazam İbrahim Paşa ile istişare etmiştir. Kendisi de bir damat olan İbrahim Paşa, muhtemelen eşi Fatma Sultan ile görüş alışverişinde bulunarak Saliha Sultan için o sırada Revan Muhafızı olan Deli Hüseyin Paşa'nın torunu Sarı Mustafa Paşa ${ }^{17}$ 'yı münasip görmüştür. Bu kararın ardından İbrahim Paşa'nın Kaftancısı İslam Bey, Mustafa Paşa’yı saraya davet etmek üzere Revan'a gönderilmiştir ${ }^{18}$. Bu davetin akabinde Mustafa Paşa'nın İstanbul'daki Kapı Kethüdası Kıbelezâde Mehmed Bey vekâletinde nişan için gerekli hazırlıklar yapılmıştır. Mustafa Paşa İstanbul'a geldiğinde kendisine yine Mehmed Bey vekâlet etmiştir. 15 Şevval 1140/28 Mayıs 1728 Pazartesi günü Mehmed Bey tarafından hazırlanan ziynetler ve diğer kıymetli eşya Saray’a gönderilmiştir. Aynı gün saat 12.30'da düğün merasimi yapılmıştır. Dügünde Mustafa Paşa'nın sağdıcı Tevkiî Ali Paşa olmuştur. Paşa tarafından gönderilen hediyeler Darüssaade Ağası Beşir Ağa marifetiyle Saliha Sultan'a iletilmiştir ${ }^{19}$.

15 BOA, TSMA.E, 201/31.

16 Bu mektupların siyasi değerlendirmesi için bkz. Ali Akyıldız, Haremin Padişahı Valide Sultan, İstanbul 2017, s. 52-53.

17 Gerek Sicill-i Osmânî'de gerekse diğer kaynaklarda Mustafa Paşa'nın Deli Hüseyin Paşa'nın oğlu olduğu yazılsa (Mehmed Süreyya Sicill-i Osmânî Yahud Tezkire-i Meşahir-i Osmaniyye, IV/I, haz. Mustafa Keskin vd., Sebil Yayınları, İstanbul 1997) da aşağıda dipnotta izah ettiğimiz üzere Mustafa Paşa, Hüseyin Paşa'nın oğlu değil torunudur. Evkaf-1 Hümayun Müfettişliği Sicillerinde, Saliha Sultan’ın kızı Fatma Sultan ile ilgili mahkeme kaydında babası Mustafa Paşa'nın Mehmed Bey'in oğlu olduğu kaydedilmiştir (BOA, EHMS, 266, s. 29). Bu kayıt üzerine tetkiklerimizi yoğunlaştırdığımızda karşımıza şöyle bir tablo çıkmaktadır: Hüseyin Paşa 1658 yılında idam edilmiştir. Mustafa Paşa babasının vefatından kısa bir süre sonra doğmuş olsa bile Saliha Sultan ile evlendiğinde en az 69-70 yaşlarında olmalıdır. İlk etapta bu mümkün olsa bile Mustafa Paşa'nın bu evlilikten çocuklarının olması sebebiyle XVIII. asırda 70'li yaşlarda bir erkeğin çocuk sahibi olabilmesi istisna kabilinden sayılacağından tarihlerimizin ve çağdaş araştırmacıların atladığı husus hem Deli Hüseyin Paşa vakfiyesinde hem de zikrettiğimiz mahkeme kayıtlarında sarih bir şekilde vakidir. Konuya dair ayrıca bkz. Yusuf Sağır, "Gâzî Hüseyin Paşa'nın Girit’teki Vakıf Eserleri”, Turkish Studies, VIII/2 (Kış 2013), s. 298.

18 Râşid, VI, s. 563.

19 Râşid, VI, s. 564. 
Ardından 10.000 tuğralı altın mehir ile ${ }^{20}$ Şeyhülislam Yenişehirli Abdullah Efendi nikâhı kıymıştır. Nikâh duasını Ayasofya Şeyhi İspirîzâde Ahmed Efendi yapmıştır. Nikâhın ardından Sadrazam'a samur kürk ferace, Tevkiî Ali Paşa'ya samur kürk ve diğer erkâna değişik hediyeler takdim edilmiştir. Neticede Saliha Sultan, Sarı Mustafa Paşa ${ }^{21}$ ile 14 Şevval 1140/24 Mayıs 1728 tarihinde nikâhlanmıştır. Nikâh merasiminin ardından Şevval'in 17. günü çeyizleri hazır edilip, bir alay ile Eyüp Defterdar İskelesi yakınındaki Sahil Sarayı'na gönderilmiştir ${ }^{22}$.

Saliha Sultan ve Mustafa Paşa'nın evliliğinden oğlu Ahmed Bey (ö.1736) ile ileride Yahya Paşa'nın kardeşi İbrahim Bey ile evlendirilecek olan Fatma Sultan ${ }^{23}$ doğmuştur. Sarı Mustafa Paşa 1731 yılında vefat etmiştir ${ }^{24}$. Saliha Sultan eşinin vefatından sonra çocukları ile Eyüp Sarayı'nda ikamete devam etmiştir ${ }^{25}$. İlk eşinin vefatından sonra dokuz yıl dul yaşamış, sonra amcazâdesi Sultan I. Mahmud tarafından 4 Rebiyülahir 1153/29 Haziran 1740 tarihinde o sırada Belgrad muhafızı olan Abdipaşazâde Ali Paşa ile evlendirilmiştir ${ }^{26}$. Aynı dönemde Safiye Sultan Bekir Paşa ile, Ayşe Sultan ise Ahmed Paşa ile evlenmiştir ${ }^{27}$. Ali Paşa bu evlilikten dört yıl sonra yani evâsıt-1 Rebiyülahir 1157/Mayıs 1744 tarihinde Diyarbakır Valisi iken eceli ile vefat etmiştir ${ }^{28}$.

Saliha Sultan üçüncü evliliğini muhtemelen 1747 y1lında Eyüp Camii İmam Hatibi Mustafa Efendi'nin oğlu Rumeli Valisi Yahya Paşa ile yapmıştır ${ }^{29}$. İlginç bir şekilde telif kaynaklarda geçmeyen evlilik ve nikâh merasimi, dönemin kroniklerinde dolaylı olarak zikredilmektedir. Padişah kızlarının evlilikleri hususunda nadir rastlanan bir durum olsa da Yahya Paşa ile Saliha Sultan'ın evli oldukları kızı Fatma Hanım Sultan'ın 1161/1748 yılının

20 Mehir: İslam Hukuku'na göre nikâh esnasında erkeğin eşine hemen veya ilerleyen süreçte vermeyi taahhüd ettiği maddi meblağdır. İki şekilde tatbik edilebilir:

Mehr-i Muaccel: Nikah esnasında tamamı verilen mehir,

Mehr-i Müeccel: Nikah esnasında tespit edilip verilmesi sonraya bırakılan mehir. M. Akif Aydın, "Mehir" DİA, XXVIII, s. 389-391.

21 Mustafa Paşa, Kapıcı Kethüdalığı'nın ardından 1725'te önce Sivas, ardından Revan Valisi olmuştur. Mehmed Süreyya, Sicill-i Osmânî, IV/I, s. 504.

22 Râşid, VI, s. 564-565.

23 Fatma Sultan 1212/1797-98 yılında vefat etmiştir. Evkaf-1 Hümayun Müfettişliği Sicilleri, 266/vr. 29a.

24 Mehmed Süreyya, Sicill-i Osmânî Yahud Tezkire-i Meşahir-i Osmaniyye, III, haz. Ali Aktan vd., Sebil Yayınları, İstanbul 1997, 504.

25 Saliha Sultan'ın 1738 yılında tesis ettiği ilk vakfiyesinde muamele için Eyüp Sarayı'nda olduğu kayıtlıdır (VGMA, 736, s. 77, sira 27/1).

26 Subhi Mehmet Efendi, Subhi Tarihi: Sami ve Şakir Tarihleri ile 1730-1744 (inceleme ve karşılaştırma metin), haz. Mesut Aydıner, Kitapevi, İstanbul 2007, s. 625.

27 Subhi, a.g.e., s. 625.

28 İzzî Süleyman Efendi, İzzî Tarihi, haz. Ziya Yılmazer, Türkiye Yama Eserler Kurumu, İstanbul 2019, s. 32.

29 Paşa'nın biyografisi ve eserleri için bkz. Mustafa Güler, "Eyüplü Yahya Paşa ve İstanbul'da ki Eserleri”, VIII. Eyüp Sultan Sempozyumu Tebliğler, 2004, s. 40-43; ayn.yzr., "Hatipzade Yahya Paşanın Rumeli'deki Eğitim ve İmar Faaliyetleri”, III. Balkanlarda İslam Medeniyeti Sempozyumu Tebliğler Kitabı, 2006, s. 413-420. 
Recep ayında, Yahya Paşa'nın kardeşi İbrahim Bey ile evliliğ $i^{30}$ ve Yahya Paşa'nın vefatından sonra Saliha Sultan'ın Ragıp Paşa ile nikâhlanması hususlarında açıkça zikredilmiştir ${ }^{31}$. Yahya Paşa evâsıt-ı Zilhicce 1168/Eylül 1755 tarihinde Tırhala Valisi iken hastalanıp birkaç gün içinde vefat etmiştir ${ }^{32}$. Dolayısı ile Saliha Sultan bir kez daha dul kalmıştır.

Saliha Sultan, Yahya Paşa'nın vefatından sonra üç yıl dul yaşamış, ardından kardeşi III. Mustafa'nın tahta geçmesiyle onun isteği üzerine ${ }^{33} 21$ Recep 1171/31 Mart 1758'de Sadrazam Ragıp Paşa ile evlenmiştir ${ }^{34}$. Osmanlı'da hanedan kızlarının evliliklerindeki teşrifat üzere gerçekleşen nişan ve nikâh merasimi sonucunda, Ragıp Paşa Saliha Sultan'a hediye olarak on altı adet kapaklı gümüş tabak, bir gümüş sini, bir kâse şeker, otuz kâse süt ve elli kâse meyve göndermiştir. Nişan töreninden 15 gün sonra nikâh yapılarak ${ }^{35}$, muhtemelen Saliha Sultan'ın arzusu ile Eyüp'teki saraya yerleşme kararı verilmiştir. Ancak Eyüp Sarayı'nda tamirat işleri devam ettiği ve Ragıp Paşa'nın Topkapı Sarayı çevresinden ayrılmasının uygun olmayacağı gerekçeleriyle Saliha Sultan, yeni eşinin sarayına yerleşmiştir ${ }^{36}$.

Ragıp Paşa'nın 24 Ramazan 1176/8 Nisan 1763'te vefatıyla ${ }^{37}$ yeniden dul kalan Saliha Sultan yine kardeşi III. Mustafa'nın arzusu ile Kaptanıderya Mehmed Paşa ile beşinci ve son evliliğini yapmıştır (8 Zilkade 1177/9 Mayıs 1764) ${ }^{38}$. Nikah, Saliha Sultan'ın Eyüp’teki sarayında icra edilmiş ve merasime Şeyhülislam Dürrizâde, Darüssaade Ağası ve Mehmed Paşa'nın kethüdası katılmıştır. Mehmed Paşa bu nikâhta 10.000 altın mehr-i müeccel tahsis etmiştir ${ }^{39}$.

Bu evlilik altı yıldan fazla sürmüş, Saliha Sultan, Mehmed Paşa ile evli iken Sadrazam Bahir Mustafa Paşa'nın onu Kaptanıderyalıktan azledip, Vidin Valiliği’ne ataması üzerine ${ }^{40}$ çok kızmıştır. Çünkü Mehmed Paşa'nın bu valiliğe atanması İstanbul'dan ayrılması anlamına gelmektedir. Hammer, Sadrazam'ın 30 Mart 1765'te azli ve sonrasında sürgün edildiği Midilli'de idamında Saliha Sultan'ın etkili olduğunu yazmaktadır. Nitekim Mehmed Paşa Vidin Valiliği'nden sonra Anadolu ve Rumeli Valiliği, Hotin Seraskerliği ve Haleb Valiliği yapmıştır. Zilkade 1184/Şubat 1771 tarihinde Tuna Sahillerindeki Yergögü Kalesi’nde yeniçeriler tarafından öldürülmüştür ${ }^{41}$.

30 İzzî Süleyman Efendi, a.g.e., s. 517; Mehmed Süreyya, a.g.e., I, s. 653; Şemdanizade Fındıklılı Süleyman Efendi, Müirittevarih, haz. M. Münir Aktepe, İstanbul Üniversitesi Edebiyat Fakültesi, İstanbul 1978, s. 140; İzzî Süleyman Efendi, s.516-517; Mehmed Hâkim Efendi, Hâkim Efendi Tarihi, haz. Tahir Güngör, I, Türkiye Yazma Eserler Kurumu, İstanbul 2019, s. 645.

31 İzzî Süleyman Efendi, a.g.e., s. 517; Hammer, a.g.e., XVI, s. 17.

32 Mehmed Hâkim Efendi, a.g.e., I, s. 309.

33 Hammer, a.g.e., XVI, s. 17.

34 Mehmed Hâkim Efendi, a.g.e., I, s. 644-645; Hammer, a.g.e., XVI, s. 20-21.

35 Hammer, a.g.e., XVI, s. 15.

36 Mehmed Hâkim Efendi, a.g.e., I, s. 646.

37 Mehmed Hâkim Efendi, a.g.e., II, s. 1102.

38 Şemdanizade, a.g.e., II, s. 16; Mehmed Hâkim Efendi, a.g.e., II, s. 1148; Şemdanizade, a.g.e., II, s. 67.

39 Nikâh merasimi ve takdim edilen hediyeler alakalı detaylı bilgi için bkz. BOA, TSMA.E, 790/39; $156 / 61$.

40 Mehmed Süreyya Sicill-i Osmânî, IV/I, s. 298.

41 Hammer, a.g.e., XVI, s. 108. 
Görüldüğü üzere Saliha Sultan'ın 13 yaşında başlayan evlilik macerası son eşi Mehmed Paşa'nın vefatı ile 56 yaşında iken son bulmuştur. Bu evliliklerin neredeyse tamamının dönemin Padişahları tarafından, Padişah kızlarının evlilikleri politikaları doğrultusunda yapıldığı görülmektedir. Biri Sadrazam olmak üzere önde gelen paşalarla gerçekleşen evliliklerin ortak noktası paşaların, Saliha Sultan ile evli iken vefat etmeleridir. Bu durum, evliliklerin paşaların ilerleyen yaşlarında gerçekleştiği sonucunu hâsıl etmektedir. Örneğin Yahya Paşa, Saliha Sultan ile evlendiğinde 50 yaşını aşmış olmalıdır. Saliha Sultan ise bu dönemde daha 30 yaşlarındadır. Keza Ragıp Paşa ile evlendiğinde Sultan 42, Paşa ise 57 yaşındadır.

Saliha Sultan'ın evliliklerinde zikredilmesi gereken bir diğer mühim nokta, Padişahların veya Sadrazamların evlilik kararı ve sonrasında bizzat kendilerine veya kurumsal olarak Padişaha verilmesi teamül haline getirilen hediye veya nakdi paraların saray harcamalarında kullanılabilmesidir ${ }^{42}$. Bu minvalde Saliha Sultan'ın Kaptanıderya Mehmed Paşa ile evliliği, Sultan III. Mustafa'nın teşviki ile olmuştur. Hammer bu teşvikteki temel argümanın Sultan Mustafa'nın Laleli Camii'nin inşası için plan dışı yaptığ 1 iki milyon kuruş harcamanın bir kısmını, bu evlilikle birlikte gerçekleştirilen üç sultanların eşlerinden tedarik ettiğini belirtmektedir ${ }^{43}$. Ayrıca bu evliliklerde damat paşanın çeyiz dışında özellikle Padişah ve varsa valide sultana takdim ettiği hediyeler bozdurulmadığı takdirde sarayda muhafaza edilirdi. Bu minvalde bugün Topkapı Sarayı'nda sergilenen kimi kıymetli eşyanın kaynağı, Padişah kızlarının düğünleri de dâhil olmak üzere evlilik ve sünnet merasimlerinde verilen hediyelerdir ${ }^{44}$.

\section{3. Çocukları}

Tespit edilebildiği kadarıyla Saliha Sultan'ın dördü kız biri erkek olmak üzere beş çocuğu olmuştur. İlk eşi Mustafa Paşa'dan, Ahmed (d.1729) ve Fatma (1730-1795?), Yahya Paşa'dan Emine (d.1750) ile 1754 yılında vefat eden Ayşe (d. 1751?-1754) doğmuştur. Mehmed Bey ile evlenen Hatice Hanım'ın babası ise kesin olmamakla beraber Ali Paşa veya Yahya Paşa olmalidir ${ }^{45}$.

Saliha Sultan'ın torunları ile alakalı kayıtlara gelince; vakıf şartnamesi gereği mütevellilik evladına intikal ettiğinden soyunu yakın zamana kadar takip etmek mümkündür. Büyük çocuğu Fatma Sultan'ın İbrahim Bey ile evliliğinden Emine Hanım ve Mehmed Bey

42 Metin And, Kırk Gün Kırk Gece, Osmanlı Düğ̈̈nleri ve Şenlikleri Geçit Alayları, Yapı Kredi Yayınları, İstanbul 2020, s. 37.

43 And, a.g.e., s. 37-38.

44 And, a.g.e., s. 70-71.

45 Alderson, a.g.e., s. 274; krş. Sakaoğlu, s. 437; Çağatay Uluçay, Padişahların Kadınları ve Kızları, Türk Tarih Kurumu, İstanbul 1985, s. 90, Özlem Başarır, Osmanlı Hanedan Kızları ve Gelirleri (XVIII. Yüzyll XIX. Yüzyllın İlk Çeyreği), Kriter Yay, İstanbul 2018, s. 25. 
doğmuştur. Sonraki dönemde Emine Hanım, Yahya Paşa’nın oğlu Ali Bey ile evlenmiş ve bu evlilikten Hatice ve Naile isimli kızları doğmuştur. Mehmed Bey’in bir oğlu Mehmed Reşid ve iki kızı dünyaya gelmiş olup adları Necibe ve Lebibe'dir. Vakıf yönetimi Mehmed Bey'in büyük kızı olduğu anlaşılan Lebibe Hanım'a intikâl etmiştir ${ }^{46}$.

\section{Vefatı ve Kabri}

Saliha Sultan 1192/1778 ortalarında istiska ${ }^{47}$ hastalığına tutulmuş, özellikle Topkapı Sarayı hekimlerinin tedavileri fayda vermeyince, o sırada oturduğu Divan Yolu'ndaki sarayından başka bir yere gitmek istemiştir. Bu doğrultuda rahat edeceği düşüncesi ile Eyüp’teki sarayına nakledilmek istenmişse de arabaya binemeyecek durumda olduğundan, nakil taht-ı revan ile yapılmıştır. Naklin ardından aynı gece vefat etmiştir (19 Ramazan 1192/11 Ekim 1778). Vefat haberi Sadrazam'a gece saat 03:00’te ulaşmış, o da haberi muhtemelen ertesi sabah Sultan'a iletmiştir. Pazartesi günü Eyüp Camii'nde Anadolu Kadıaskeri tarafından cenaze namazı kıldırılmıştır ${ }^{48}$. Saliha Sultan Eyüp Sultan Türbesi'nin batı tarafına defnedilmiştir. Mezar taşı yekpare mermerden oyularak meydana getirilmiştir. Kitabe şöyledir:

Hüvel Hallaku'l Baki

Dohter-i Sultân Ahmed hâher-i Şâh-ı cihân

Saliha Sultân ya 'nî Hak ânı mağfûr ide

Hastgâr-i hayr idi ol küll-i iffet dâimâ

Âlem-i uhrâda dâhi hayr ile me'cûr ide

Sâlihât-i ümmet ile haşr olup rûz-i cezâ

Dehşet-i Mahşerde ânı Hak Teâlâ dûr ide

Ka be-i hâcât idi Bâb-ı Sarây himmeti

Sa yi ihsân idi çun kim, sa yini meşkûr ide

Hiç olmaz böyle târîh-i duâgû Ârifâ

Saliha Sultan'in Allah kabrini pürnûr ide $1192^{49}$

Hemen yanında 1 Muharrem 1238/12 May1s 1823 tarihinde vefat eden torunu Emine Hanım Sultan'ın kabri vardır ${ }^{50}$. Sarayının Eyüp Sultan'da olması, Eyüp Camii’ne vakıflar yapması ve buraya defnedilmesinden hareketle, onun Eyüp Sultan semtine bağlılığını ve Ebu Eyyub el-Ensari külliyesine karşı muhabbetini görebiliriz. Ayrıca türbenin yanına defnedilmesindeki temel âmilin kendi vasiyeti olduğunu düşünüyoruz.

46 BOA, EHMMS, 266, vr. 29.

47 Tıptaki adı hidropsi olan vücudun bazı yerlerinde su toplanması şeklinde oluşan hastalıktır. Osmanlıca Tip Terimleri Sözlüğ̈̈, haz. Ekrem Kadri Unat-Ekmeleddin İhsanoğlu-Suat Varol, Ankara 2004, s. 273.

48 Ahmed Cevdet Paşa, Tarih-i Cevdet, I, haz. Nezihi Aykut, Türk Tarih Kurumu, Ankara 2018, s. 107-108.

49 Bkz. Ekler Resim 7.

50 VGMA, esas 787/336-337. 


\section{Muhallefâtı ve Mukataaları}

Yukarıda temas ettiğimiz üzere Saliha Sultan, 19 Ramazan 1192/11 Ekim 1778 tarihinde vefat etmiştir. Vefatının hemen ardından Şevval ayında her iki sarayında bulunan muhallefâtının tespitine başlanmış ve aynı ayda bitirilmiştir. Yapılan muhallefât tespitinin ardından eşyaların adetleri yazılarak Enderun Hazinesi'ne aktarılmıştır ${ }^{51}$. Ardından muhallefâttan çıkarılacak meblağın hesaplaması yapılıp, toplam meblağdan ilan ve yazım masrafları, Eyüp'den Topkapı Sarayı'na nakil ve taşıma ücretleri çıkarılmıştır. İlave olarak Saliha Sultan'a 3.000 kuruş borcu olan Ahmed Efendi'nin ödemesi de hesaba eklenmiştir. Vefatı sonrasında defin için 1.352 kuruş harcanmış, 24.094 kuruş olan borcu ödenmiştir. Sonuç olarak Saliha Sultan'ın muhallefâtından 25.386,5 kuruş 44 para elde edilmiş, masrafların 25.446 kuruş hesaplanmasıyla da 59 kuruşluk açık çıkmıştır ${ }^{52}$.

Vefatından hemen sonra Şevval ayında yapılan tespite göre, Saliha Sultan'ın üzerinde bulunan mukataaları şunlardır: Aclun ve Leccun ${ }^{53} 16.300$ kuruş, Biga 1.897 .980 akçe, Girit zeytinyağı ve sabun 20.130 kuruş, Karahisar-i Şarki ${ }^{54} 3.800 .700$ akçe $^{55}$, Fatih Emir Buhari' de bir bostan 50 kuruş, Tütün Gümrügüünden 960 kuruş, Mora Adası'nda mesire panayırı kurulan handa günlük 40 akçeden aylık 11 kuruş $^{56}$.

Tespitin yapılmasından sonra detaylı muhasebesi yapılan bu işletmeler Saliha Sultan'ın mülkü olmadığ için talibine veya hanedan mensuplarından birine satılmak üzere emanete alınmıştır ${ }^{57}$.

\section{Vakıfları}

Saliha Sultan, 1151-1190/1738-1776 yılları arasında yedi vakfiye tescil ettirmiştir. Bu vakfiyelerin ilki 1151/1738 tarihli olup asıl hükmündedir. Sonraki tarihlerde ise ilk vakfiyeye akar ekleyerek, hayır şartını değiştirerek ya da yeni hayır şartları ekleyerek zeyl vakfiyeler düzenletmiştir. Onun adına Vakıflar Genel Müdürlüğ̈̈nde kayıtlı olan son vakfiye ise 27 Muharrem 1192/25 Şubat 1778 tarihli olup, 27 Muharrem 1190/12 Mart 1776 tarihli vakfiyesindeki akarlardan ikisi burada bulunmamaktadır. Ayrıca bu vakfiyede elde edilen gelirlerin harcanması tamamıyla Saliha Sultan ve çocuklarına bırakılmıştır ${ }^{58}$. Saliha Sultan'ın

51 BOA, TSMA.D, 7666/1-3.

52 BOA, TSMA.E, 232/1-1.

53 Aclun ve Leccun: Bugün Ürdün sınırlarında kalan iki yerleşim yeri.

54 Bugünkü Şebinkarahisar.

55 Başarır, a.g.e., s. 234.

56 BOA, TSMA.D, 9496/1-1; Başarır, a.g.e., s. 26.

57 Hanedan Kızlarının mukataa işletmeleri ve isimleri ile ilgili bkz. Başarır, a.g.e., s. 232-243. Saliha Sultan'ın hem muhallefâtı hem evliliklerinde takdim edilen hediyeler hem de mukataaları sistem olarak bu makalenin konusunu aşacağından dahil edilmemiştir.

58 VGMA, 747 s.113 sira 109, vakfiyede gelirlerin tamamı diğer evlatlık vakıflarda olduğu gibi kurucunun kendisine ve ahfadına şart edilmiştir. Ancak aşağıda muhasebe defterlerinde görüleceği üzere son vakfiyedeki bu şart gerçekleşmemiştir. Bu durumda ya Saliha Sultan'ın vefatından yaklaşık 9 ay önce tanzim edilen bu şart yanlışlıkla yazılmış ya da daha sonradan düzeltilmiş olmalıdır. 
Vakıflar Genel Müdürlüğü Arşivi'nde bulunan vakfiyeleri tarih sırasına ve özelliğine göre şöyledir:

\begin{tabular}{|c|c|c|}
\hline Yeri & Tarihi & Maksadı \\
\hline VGMA 736, s. 77. sira $27 / 1$ & 2 Cemaziyelevvel 1151/18 Ağustos 1738 & İlk vakfiye ${ }^{59}$ \\
\hline VGMA 739, s. 235. sira 139 & 15 Zilkade 1152/13 Şubat 1740 & $\begin{array}{l}\text { İlk vakfiyedeki bir hayır şartının } \\
\text { değiştirilmesi }\end{array}$ \\
\hline VGMA 741, s. 249. sira 142 & 27 Muharrem 1190/12 Mart 1776 & Ek akarlar ve tevliyet \\
\hline VGMA 741, s. 50. sira 143 & 21 Safer 1990/11 Nisan 1776 & Ek akar ve ek hayır \\
\hline VGMA 736 , s. 77 . sira $27 / 2$ & 27 Safer 1990/17 Nisan 1776 & Cibayet ${ }^{60}$ ve kitabet \\
\hline VGMA 741, s. 251. sira 144 & 4 Rebiyülevvel 1190/23 Nisan 1776 & $\begin{array}{l}\text { Anne ve babasinın ruhuna Kur'an } \\
\text { okunması }\end{array}$ \\
\hline VGMA 747, s. 113. sira 109 & 27 Muharrem 1192/25 Şubat 1778 & Bir kısım akar ve harcama şartı \\
\hline
\end{tabular}

Saliha Sultan'ın vakfiyeleri içinde kitap vakıfları geçmese de Hekimoğlu Ali Paşa Kütüphanesi'ne bağışladığı kitapların üzerindeki vakıf mühürleri, bu kütüphaneye kitap bağışladığını ortaya koymaktadır ${ }^{61}$.

Yukarıdaki tabloda görüleceği üzere Saliha Sultan 1151-1192/1738-1778 tarihlerinde vakfiyeler tanzim ettirmiştir. Bu çalışmada vakfiye transkripsiyonu ve tahlili yapılmayıp, vakfı ve değişimini ortaya koyan bir yaklaşımla konu ele alınacaktır. Bu usulden hareketle öncelikle vakıfların tesis ve yönetim sistemi, ardından akarları ve hayratı, son olarak da günümüze uzanan süreçteki ahvali ortaya konulacaktır.

\section{a. Vakıflarda Tesis ve Yönetim Sistemi}

Osmanlı hanedanının hanım mensupları çok sayıda vakıf tesis etseler de dönemin örfi ve siyasi teamülleri gereği -nikâhları da dâhil- yaptıkları hukukî ve medenî muamelelere genelde vekillerini göndermişlerdir. Aynı uygulamanın hanedanın erkek mensupları ve üst bürokraside görev yapan devlet adamları için de mevzubahis olduğunu söylememiz mümkündür. Saliha Sultan ilk vakfiyesini 2 Cemaziyelevvel 1151/18 Ağustos 1738 tarihinde Eyüp Sultan'daki sarayında tanzim ettirmiştir. Saliha Sultan'ın vakfın kurulması hususundaki mutlak vekili Darüssaade Ağası Beşir A ğa'dır. Ancak Beşir Ağa’nın, meclise bizzat gitmediği; yerine yardımcılarından Ali Ağa'yı gönderdiği görülmektedir ${ }^{62}$.

59 Bu vakfiyenin bir nüshası da aşağıda zikredeceğimiz Saliha Sultan'ın Göksu'da mevcut Hasan Paşa ve Sultan Bayezid Bahçeleri mülkiyeti meselesinde istinsah edilmiş olarak BOA, YA.RES, 148/27-4-1'de bulunmaktadır.

60 Cabi: Vakıf gelirlerini tahsil eden görevli. Şemseddin Sami, Kâmûs-i Türkî, İstanbul 2011, s. 370.

61 Günay Kut-Nimet Bayraktar, Yazma Eserlerde Vakıf Mühürleri, Ankara 1984, s. 56; Hülya Tezcan, Osmanlı Sarayının Çocukları, İstanbul 2006, s. 209.

62 Bu kayıttan Saliha Sultan'ın ilk eşi Mustafa Paşa'nın vefatından sonra Eyüp Sultan' da yaşadığı neticesine de varabiliriz. VGMA, 736, s. 77, sira 27/1. 
Burada dikkat çeken bir husus vakfiyede iki adet tevliyet şartının bulunmasıdır. Bunlardan birincisi tesis sirasında tayin edilen mütevelli Mehmed Ăga'dır. İkincisi ise "vakf-ı mezbur dahi lâbis-i libas-ı hayat oldukça kendilere badeha evlâd-ı emcadlarına ve evlâd-ı evlâd-ı evlâtlarına badehüm utekalarına ve evlâd-ı evlâd-ı utekalarına badehüm re'yi nazır-ı müşarun ileyh hazretlerine menut olup mürur-ı eyyam ve kurur-l şuhur ve a'vam ile vakf-ı mezbure fütur tari olup şurut-ı mezkûreye riayet müteazzir olur ise mutlaka fukarayı müslimine vakf ola" şeklinde ifade ederek 20 akçe yevmiye ile önce kendisine sonra evladına şart edilmesidir. Bu şarta ilave olarak neslinin kesilmesi durumunda paranın Darüssaade Ağası marifetiyle fukaraya tahsisini istemiştir. İki mütevellilik alışılmışın dışında bir uygulamanın varlığını ortaya çıkarmaktadır. Vakfın mütevelliliği ile tevliyet ciheti ayrılmış, yani Saliha Sultan tevliyet cihetini kendine ve evladına şart etmiş ancak vakfın yönetimini mütevelli Mehmet Ağa'ya tahsis etmiştir.

Saliha Sultan'ın 1190/1776 yılında tesis ettiği vakıflarda kuruluş ve yönetim sistemi ise şöyledir: Bu vakfiyede belki öncekine zeyl belki de o sırada Darüssaade Ağası Sarıç̧ı Beşir Ağa'nın ${ }^{63}$ selefi Hacı Beşir Ağa gibi, padişahlar diğer hanedan mensupları nezdinde etkili olmamasından dolayı, vekil olarak Saliha Sultan'ın Baş Ağası Ahmed Ağa ibn Abdullah kaydedilmiştir. Vakıf muamelesi için İstanbul Kadılığı veya Evkaf-1 Hümayun Müfettişliği Mahkemesi Ahmed Efendi isimli bir kâtip veya kadı naibi göndermiştir. Vakıf muamelesi muhtemelen o sırada Saliha Sultan'ın ikamet etmekte olduğu Divanyolu Rüstem Paşa Mahallesi'ndeki sarayda tahakkuk etmiştir. $\mathrm{Bu}$ dönemde vakfın mütevelliliğine Yahya Paşa'nın oğlu Ali Bey tayin edilmiştir. Ali Bey Saliha Sultan'ın kethüdası ve aynı zamanda kapıcıbaşısıdır.

Son olarak belirtmek isteriz ki bu dönemde de hanedan mensuplarının tüm vakıfları gibi tesis sistematiğini zikrettiğimiz Saliha Sultan Vakıfları, Darüssaade ağalarının nezaret ettikleri Haremeyn Evkaf Nezareti tarafından idare edilmektedir. Saliha Sultan Vakıflarında Haremeyn'e dair tek tahsis şartı ise 1152/1740 tarihinde tesis ettiği zeyl vakfındaki evlâdiyet üzere kurduğu tevliyet cihetinin inkırazdan sonra Medine-i Münevvere vakfına ilhak olunmasidir ${ }^{64}$.

\section{b. Saliha Sultan'ın Vefatından Sonra Vakıf Mütevelliliği}

Yukarıda geçtiği üzere Saliha Sultan hayatta iken vakfının mütevelliliğini kendisi veya vekâleten kethüdaları yürütmüş olmalıdır. Vefatından sonra ise; o sırada hayatta olup yaşça büyük kızı Fatma Hanım Sultan bu vazifeyi deruhte etmiştir. Belgelerden vakfın sonraki dönemlerdeki tevliyetini iki istisna dışında Fatma Hanım Sultan'ın büyük çocuklarının ve

63 1187-1193/1773-74-1779-80 yılları arasında Darüssaade Ağasıdır. Ahmed Resmi Efendi, Hamiletü’l-Kübera, haz. Ahmet Nezihi Turan, Kitabevi Yay., İstanbul 2000, s. 171.

64 VGMA, 739, s. 235, sira 139. 
torunlarının yürüttükleri görülmektedir. Ayrıca Fatma Sultan ve torunları Saliha Sultan Vakfı dışında, büyük dedeleri Gazi Hüseyin Paşa vakıflarının tevliyetini de yürütmüşlerdir. Fatma Hanım'ın büyük kızı Emine, ikinci kızı Hüveyle Hanım'dır. Oğlu ise Mehmed Reşid Bey'dir. Emine Hatun hayatta iken büyük kız sıfatıyla mütevelliliği sürdürmüş, ardından Hüveyle Hatun 1242/1826-27’ye kadar bu vazifeyi yürütmüştürr ${ }^{65}$.

\section{Tablo 2: Emine Hatun'un çocuklarından sonraki mütevellilerin listesi}

\begin{tabular}{|l|l|l|}
\hline Adı & Akrabalık Durumu & Tarih \\
\hline Hatice & Ali Bey'in Kızı & $1242-1247$ \\
\hline Naile & Ali Bey'in Kızı & $1247-1262^{66}$ \\
\hline Şerife Lebibe & & $1262-1270^{67}$ \\
\hline Mehmed Râşid & & $1270-1277$ \\
\hline Abdurrahman İzzet & Mehmed Reşid Beyin küçük kızı & $1277-?$ \\
\hline Ayşse Hanım & Mehmed Reşid Beyin oğlu & $?-1286$ \\
\hline Zeynep Hanım ${ }^{68}$ & Salih Bey'in Kızı & $1286-1309$ \\
\hline Hüseyin Hüsnü & & $1309-1313$ \\
\hline Fatma Adile & Zeynep Hanım'ın büyük oğlu & $1313-1337^{70}$ \\
\hline Şerife Feride & & $1337-1927^{72}$ \\
\hline
\end{tabular}

Hem vakıf arazilerinin tasarrufu hem de yönetimine dair dair ilginç bir olay 1325/1907 yılında meydana gelmiştir. Şöyle ki; anılan dönemde Küçüksu'da birbirine bitişik 800 zira büyüklüğündeki iki arsanın yönetimi Saliha Sultan'ın evladından olmayan Kahveci Cavid Ağa'da iken, onun vefatıyla tevliyet mahlûl kalmıştır. Bu gelişme üzerine dönemin hukuki muamelesi gereğinde tevliyetin müzayede ile ilana çıkılarak talibine verilmesi gündeme gelmiştir. Vakıf şartnamesi icabı Haremeyn'e mülhak kabul edilen Saliha Sultan vakıf akarının tevliyeti için sürdürülen atama sürecinde Fatma Adile Hanım, Evkaf-ı Hümayun Nezareti’ne bir istida sunarak, Saliha Sultan'ın torunlarından olduğunu ve tevliyetin kendisine intikalinin gerektiğini belirtmiştir. Sunulan dilekçe ve vakfiye şartı doğrultusunda, zikredilen iki arazi

65 VGMA, 787, 336-337.

66 BOA, EV, 38215, vr. 86 b.

67 BOA, EV, 38215, vr. 19 b.

68 1286/1869-70 tarihinden itibaren mütevelliliği yürüten Zeyneb Hanım'ın 1293/1876-77 tarihli kayıtta oğlu olarak Pertev Bey kaydedilmiştir (EV 38215, vr 1b); ancak 24 Cemaziyelevvel 1309/26 Aralık 1891 tarihinde Zeyneb Hanım vefat etmiş ve mütevellilik o sırada hayatta olan büyük oğlu Hüseyin Hüsnü Bey’e intikal etmiştir (VGMA, esas 120/1773), Bu durumda Pertev Bey annesinden evvel vefat etmiş olmalıdır.

69 VGMA, esas 120/1773.

70 BOA, YA.RES, 148/27-1.

71 Fatma Adile Hanım, 1336 yılında vefat etmiş ve yerine Şerife Feride Hanım tayin edilmiştir, vakıf kaydında Feride Hanım ile alakalı olarak kurucunun evladından olup olmadığına dair bir bilgi bulunmasa da, biz isminden hareketle onun da Saliha Sultan'ın torunlarından biri olduğunu düşünüyoruz. Feride Hanım Osmanlı döneminde son, Cumhuriyet döneminde ilk mütevelli olarak vazife yapmıştır.

72 VGMA, esas 120/1773. 
ile Sultan Bayezid, Hasan Paşa Bahçelerinin yönetiminin Fatma Adile’ye verilmesi gündeme gelmiştir. Neticede yazışmalara konu olan temlikname ve vakfiyeye göre tevliyet ve gelirler Fatma Adile Hanım'a tahsis edilmiştir ${ }^{73}$.

Sonuç olarak belirtmek isteriz ki Saliha Sultan Vakıfları, Deli Hüseyin Paşa Vakıfları ile birlikte Osmanlı Devleti'nin son dönemine kadar hatta Cumhuriyet döneminde de Fatma Sultan'dan olan torunları tarafından idare edilmiştir. Evkaf-1 Hümayun Nezareti'nin kurulmasından sonra sistem tamamen değişmiş ise de Saliha Sultan Vakıflarında tevliyet, evladı üzerinden devam ettiğinden inkıraza bağlı Haremeyn şartı gerçekleşmemiştir. Ancak son dönem belgelerinde mezkûr vakıfların Haremeyn'e tâbi olduğu kaydedilmiştir ${ }^{74}$.

\section{c. Vakfin Akarları}

İslam döneminde ve tabiatıyla Osmanlı asırlarında hanedanın erkek mensupları gibi hanım mensupları da yüksek meblağlar tutan hayır eserlerine imza atmışlardır ${ }^{75}$. Yukarıda kuruluş tarihleri ve yönetim sistemini ele aldığımız vakfiyelerde zikredilen toplam on üç akar bulunmaktadır. Saliha Sultan bu akarlardan biri hariç tümü için mülküm olan ifadesini kullanmaktadır. Cağaloğlu Hoca Rüstem Mahallesi'nde dört dükkân ve dükkânlara bitişik beş yüz on zira arsa üzerinde müştemilatlı bir $\mathrm{ev}^{76}$ dışındaki aşağıda zikredilecek olan gayrimenkullerin üç tanesi Saliha Sultan’a babası veya kardeşleri olan padişahlar tarafindan temlik edilmiş, on tanesi ise kendisi veya kethüdaları tarafından onun adına satın alınmıştır. $\mathrm{Bu}$ tespitten sonra vakfiyelerdeki sırası ile vakıfların akarlarının zikrine geçebiliriz:

1- Beykoz Göksu'da Sultan Bayezid Bahçesi'nde arazi ve tarla, akar, su kuyuları ve diğer müştemilatı olan bahçeler,

2- Göksu'da Hasan Paşa Bahçesi’nde arazi ve tarla, kuyular çayır gibi birimlerden oluşan mülk bahçeler ${ }^{77}$,

Saliha Sultan'ın ilk vakfiyesinde akar olarak kaydettirdiği üç gayr-i menkulden ilk ikisi gurre-i Receb 1139/22 Şubat 1727 tarihinde babası Sultan III. Ahmed tarafindan temlik edilmiştir. Saliha Sultan vakfiyesinde açık olarak mülküm ifadesini kullanmasına rağmen bu temlikname Patrona Halil İsyanı sırasında veya daha sonraları kaybolmuş olmalıdır. XIX. asırda ortaya çıkan parselleme ve para takipleri hususlarından dolayı temliknamelere

73 BOA, YA.RES, 148/27/3-1

74 VGMA, 780, s. 23, sira 35.

75 Hanedan kızlarının gelir kalemleri için bkz. Başarır, a.g.e., s. 13-15, 19-20; Saadet Maydaer, "Osmanlı Toplumunda Vakıf Kuran Kadınlar ve Mal Varlıklarının Kaynakları", Vakıf Kuran Kadınlar Sempozyumu Tebliğleri, Vakıflar Genel Müdürlüğü Yayınları, Ankara 2019, s. 146-151.

76 VGMA, 741, s. 249, sayfa 142 .

771151 tarihli İlk Vakfiye VGMA, 736, s. 77, sıra 27/1; Vakfiyenin 10 Şaban 1322 tarihinde tevsik edilen sureti için BOA, YA.RES, 148/27-4-1. 
müracaat edilmesi gerekmiştir. $\mathrm{Bu}$ halde mezkûr temliknamelerin nüshaları ilk olarak defterhaneden istenmiştir. Burada bulunamayınca tetkikat derinleştirilmiştir ${ }^{78}$. İkinci olarak yazışma yapılan Divan-ı Hümayun Kalemi’nde kayıt olmadığg görülünce Maliye Kalemi’ne oradan da Evkaf-1 Hümayun Evamir Kalemi'ne yazılmıştır ${ }^{79}$. Nihayet Maliye Nezareti Muhâsebât-1 Atîka Kalemi'nde bulunabilen temliknameler sayesinde mülkiyet durumu yeniden tevsik edilmiştir ${ }^{80}$. Temliknameye göre Göksu'daki Hasan Paşa Bahçesi Sultan III. Ahmed'in has bahçelerinden olup senelik geliri 15.000 akçedir. Bu durumda geliri doğrudan Enderun Hazinesi'ne aktarılırdı. Saliha Sultan'a ikinci olarak mutlak temlik edilen Sultan Bayezid Bahçesi'nin geliri ise yıllık 14.000 akçedir $^{81}$.

$\mathrm{Bu}$ akarlar sağlam bir temlik ve vakıf şartı sistematiğine sahip olsa da özellikle XIX. yüzyılda vakıfların uğradığı siyasi ve hukuki sıkıntılardan etkilendikleri muhakkaktır ${ }^{82}$. Bir de yüzyılın başındaki idari değişiklikler, akarlar ve hayrattaki takip ve muhasebeyi zorlaştırmıştır. Ayrıca tevliyetin sadece gelir kaynağı olarak görülmesi nedeniyle, çoğu vakıf hayratı ve akarı taarruza açık hale gelmiştir. Tüm bu olumsuzluklara akarların arazi ve diğer varlıklarındaki rant yükselmesi, imara açılma ve sahipsizlik gibi durumlar da eklenince, önce hayrat şartları yerine getirilememiş sonra da değişik usullerle akarlar mahiyet değiştirmeye başlamıştır. Vakfiyede sadece Hasan Paşa ve Sultan Bayezid bahçelerinden bahsedilirken, XIX. asrın ikinci yarısından itibaren bu arazilerin ikiye ayrıldığı görülmektedir. 15 Safer 1293/12 Mart 1876 tarihli Evkaf-1 Hümayun Nezareti'nden yazılan tezkireye göre bahçelerin muhtemelen sahile bakan kısmının arkasında bulunan 2.481.678 zira (yaklaşık 1.861.258 metrekare) arsa ifraz olunarak 154.316 ziraı bağ-bahçe, 536.544 ziraı bostan-çayır, 166.275 ziraı yeni açılacak yollara, 8.355 ziraı tekke yeri, 1.000 arşın (yaklaşık 700 metrekare) karakolhane olarak planlanmıştır ${ }^{83}$. Araziden geri kalan aktif kısımlar ise ev ve dükkân inşa edilip kiralanmak üzere Mütevelli Şerife Zeynep Hanım’ın dilekçesi ile talep edilmiştir. Ancak bahsi geçen yerlerin taşlık ve yapılaşmaya uygun olmadığı görüldüğünden arazilerin bağ ve bahçe yapılmak üzere parça parça kiralanması gündeme gelmiştir ${ }^{84}$. 26 Safer 1292/3 Nisan 1875 tarihli irade-i seniyye ile tespit edilen dönüm başına 40 kuruşluk mukataa bedelinin tenzili mevzubahistir. Özellikle üzerine ev yapılacak olan kısımların her 100 zira1 için senelik 60 akçe, bağ ve bahçe olacak kısımlar içinse her dönüme senelik 6 kuruş mukataa takdir edilmiştir. Bu rakamların 25 Cemaziyelevvel 1315/22 Ekim 1897 tarihinde de tatbiki hakkında karar verilmiştir ${ }^{85}$.

78 BOA, BEO, 103858/2-1.

79 BOA, BEO, $1038581 / 1$.

80 BOA, YA.RES, 148/27-5-1.

81 BOA, YA.RES, 148/27 5-2.

82 Bu arazilerdeki mahiyet değişikliğine dair örnek için bkz. Nazif Öztürk, Türk Yenileşme Tarihi Çerçevesinde Vakıf Müessesesi, TDV Yayınları, Ankara 1995, s. 270.

83 BOA, EV, 38215, 1b.

84 BOA, EV, 38215, $1 \mathrm{~b}$.

85 BOA, ŞD, 2680/26-1-1. 
Her iki bahçe hem büyük hem de geliri yüksek olduğundan ilerleyen zamanlarda yapılaşmaya ve taksime uğramıştır. Gelişmeler böyle olsa da Sultan Bayezid ve Hasan Paşa bahçelerinden yukarıda miktarı yazılı arazilerin Saliha Sultan'a temlik edilmesi ve en azından tevliyetinin onun varislerinden biri üzerinde bulunması halinin XX. yüzyılın başlarında devam etmekte olduğu görülmektedir ${ }^{86}$.

3- Küçükçekmece'de evler ve diğer müştemilatı olan çiftlikler ${ }^{87}$.

Saliha Sultan'ın vakfiyesinde ilk iki akarın babası tarafından kendisine temlik edildiğine dair mevcut arşiv kayıtlarına rağmen aynı vakfiyedeki üçüncü akarın da temlik edildiği ve diğerleri gibi temliknamenin olduğu kayıtlıdır. Hem vakfiyenin evlilikten bir süre sonra tanzim edilmiş olması hem de bazı evkaf defterlerinde Saliha Sultan ile büyük kayınpederi Hüseyin Paşa'nın muhasebelerinin aynı yerde olmasından hareketle arazilerin Sarı Mustafa Paşa'dan miras veya temlik yoluyla intikal ettiğini söylemek mümkündür.

Bu arazi 1260/1844-45 yılında Beylik Çiftliği olarak isimlendirilmiştir. Çiftlik, araziler, mera, bahçe, bağ ve tarlalardan oluşmakta olup senelik icare- $i$ vahidesi ${ }^{88} 3.500$ kuruş olarak tayin edilmiş ve Dîvân-1 Hümâyun hocalarından El-Hac Ahmed Hulusi Efendi'ye kiralanmıştır ${ }^{89}$. Arazinin 1294/1877-78 yılındaki büyüklüğü bir ev bağ ve bahçe toplamı 656 dönüm 21 parça tarla ve bir miktar çayır olup teferruatı evkaf muhasebe defterinde şu şekilde yer almıştır.

\section{Tablo 3: Küçükçekmece'deki Arazilerin Teferruatı}

\begin{tabular}{|l|l|}
\hline Arazi Adı & Büyüklüğü veya geliri \\
\hline Bayırbaşı tarlası $^{90}$ & - \\
\hline Sakız tarlası1 $^{91}$ & 60 kile \\
\hline Nazik bahçesi & 4 dönüm \\
\hline Büyükçekmece Gölü kenarında Dalyan tarla & 4 kile \\
\hline Büyükçekmece Gölü başka bir tarla & 4 kile \\
\hline Florya tarlası yanında Anbar Batlaran tarlası & 12 semen \\
\hline
\end{tabular}

86 Oldukça geniş ve rantı yüksek bir mekân olan bu araziler ile alakalı gerek 1290/1873-74'lı yıllarda gerekse 1325/1907-08 yıllarında çokça arazi meselesi gündeme gelmiş olup bu konular, çalışmanın şu anki muhtevasını ilgilendirmediğinden detaya girmiyoruz.

87 VGMA, 736, s. 77, sira 27/1.

88 İcare-i Vahide: Ay ve sene gibi bir vakit ile muvakkat olarak mütevellisi veya tevliyet vazifesini gören zat tarafindan ecr-i misliyle taliplerine kiralanan akardır. https:/www.vgm.gov.tr/kurumsal/tarihce/vakifdeyimleri-ve-terimleri-sozlugu erişim tarihi, 4.10.2021.

89 BOA, EV, 38215, 5b.

90 Bu tarla defterde teferruatlı olarak tarif edilmiş olup şu an Küçükçekmece Soğuksu Parkı civarındadır.

91 Evkaf muhasebe defterinde arazilerin birinde dönüm diğerinde kile ifadesi kullanılmaktadır. Biz kile olarak zikredilenleri senelik tahmini gelir olarak değerlendirdik.

92 Günümüzde Büyükçekmece Gölü etrafında Dalyan isimli yer adlarından hareketle her iki tarlanın da bugünkü Büyükçekmece Gölü’nün doğu tarafinda olduğunu düşünüyoruz bkz. Ekler 1 . 


\begin{tabular}{|l|l|}
\hline Hacı İbrahim Çeşmesi üstünde tarla & 6 kile \\
\hline İncirtepe mevkiinde tarla (Florya'da) & 16 kile \\
\hline Kanlıkapı mevkiinde tarla (Florya'da) & 15 kile \\
\hline Sepetçi yolu altında tarla (Florya'da) & 15 kile \\
\hline Kaliktarya tarlası (Florya) & 80 kile \\
\hline Dalyan burnunda tarla (Büyükçekmece Gölü Kıyısında) & 10 kile \\
\hline Sakra hudud dahilinde bir tarla93 & 7 kile \\
\hline Florya'da tarla & 8 kile \\
\hline Karaçalı bir tarla (Florya'da) & 30 kile \\
\hline Posta yolu üstünde tarla & 3 kile \\
\hline Küçükçekmece'de Abdüsselam Bey İmareti karşısında Bademli Bahçe & 5 kile \\
\hline Kumsal94'da bostan & 3 kile \\
\hline Kumsal'da diğer bostan & 1 kile \\
\hline Kumsal'da harab băg & 4 kile \\
\hline Küçükçekmece Çiftliği yanında Narlı Bahçe & 5 dönüm, 5 kile95 \\
\hline
\end{tabular}

Liste incelendiğinde zikredilen arazilerin bugünkü Bakırköy'den başlayarak Büyükçekmece Gölü civarı ve Büyükçekmece Gölü’nün güney batı sahillerine kadar uzanan alanda olduğu görülecektir. Daha çok Marmara Denizi sahili ve göl kenarlarında yer alan araziler Osmanlı'nın son dönemine kadar vakıf akarı olarak muhafaza edilmiş, ancak 1924 'ten ve 1936'dan sonra satış, devir, imar düzenlemesi gibi yollar ile bu akarlar vakfın elinden çıkmıştır.

4- İstanbul Bayezid Soğanağa Mahallesi'nde üç katlı ve bahçeli bir evº,

Bu mülke dair sonraki dönemde tutulan muhasebe defterlerinde bir kayıt bulunmamaktadır. Bu durum akla ya Saliha Sultan hayatta iken bir şekilde akarın mahiyetini kaybettiği ihtimalini ya da sonraki dönemlerde bir şekilde elden çıktığı hususunu akla getirmektedir.

5- İstanbul Mahmud Paşa Cezerî Kasım Paşa Mahallesi'nde 330 zira arsa üzerinde 3 katlı müştemilatı olan bina ve bahçesi,

Saliha Sultan'ın vefatından bir yıl sonra evin aylık kirası 45 akçe olup, mutasarrıfı Gülşen Hatun binti Hayrullah isimli hanımdır. Gülşen Hatun bu hissesinin yarısından ferağ edip, Seyyid Mehmed Emin ibn el-Hac Feyzullah'a devretmiştir (15 Cemaziyelahir 1193/30

93 Listede geçen, Nazik Bahçesi, Anbar Batlaran tarlası, Hacı İbrahim Çeşmesi üstü, Sakra Hudud tarlası gibi mekanların bugünkü mevkileri tespit edilememiştir.

94 Bu ve sonraki iki mekân bugünkü Büyükçekmece Gölü’nün güney batısında Marmara Denizi'nin sahilleri olmalıdır.

95 BOA, EV, 38215, vr.18b.

96 VGMA, 741, s. 250, sira 143. 
Haziran 1779) ${ }^{97}$. Mezkûr arsa ve evin tasarrufu 1245/1829-30 tarihinde es-Seyyid Mehmed Efendi'nin ferağı sonrasında el-Hac Veli Ağa ibn Hüseyin tarafindan tasarruf edilmeye başlanmıştır ${ }^{98}$.

6- Küçükçekmece'de iki katlı ev ve bahçesi,

1195/1780-81 yılı vakıf kayıtlarında Saliha Sultan'ın bu arazisinin Küçükçekmece’ye bağlı Avas Köyü'nde olduğu kayıtlıdır ${ }^{99}$. Bu tarihte bahçıvan evi, havuz ve ağaçlı bahçeden oluşan arazinin büyüklüğü 7.000 zira olup aylık kirası 60 akçedir. Anılan tarihte ev ve bahçe es-Seyyid el-Hac Mehmed Emin Ağa ibn El-Hac Hasan Ağa tarafından tasarruf edilmektedir ${ }^{100}$.

7- Küçükçekmece kumsalda üzüm bağı ve bahçe,

Küçükçekmece'de son sayılan bu iki akar 27 Cemaziyelevvel 1273/23 Ocak 1857 tarihi itibarıyla yıllık 4.000 kuruş peşin kira ve 51 kuruş daha sonra tahsil edilmek üzere Yazıcıbaşı Yakup Bey’e kiralanmıştır ${ }^{101}$.

8- Kasımpaşa'da Yeldeğirmeni Mahallesi'nde 2.591 zira arazide evler ve bahçeler,

$\mathrm{Bu}$ gayrimenkule ait bir hane 1262/1845-46 tarihinde Keresteci Abdullah ibn Yakup uhdesinden aylık 90 kuruş kira ile oğlu İsmail ve kızları Hafize ve Saliha’ya intikal etmiştir ${ }^{102}$.

9- Fatih Hırka-i Şerif Yenibahçe'de Kuseyil tarlasının 3.000 akçe mukataa geliri,

$\mathrm{Bu}$ bahçe daha Saliha Sultan hayatta iken Yano adında bir gayrimüslime yıllık 14.000 akçe karşılığında kiraya verilmiştir. Kiracıdan yapıların olabilecek tamir ve bakımını da üstlenmesi istenmiştir ${ }^{103}$. Bu arazi sonraki dönem muhasebe defterlerine beylik bahçe olarak kaydedilmiş, iki bostandan oluşmaktadır. 1259-1260/1843-44-1845 yılları için yı1lık 275 kuruş icare-i vahide ile üç gayrimüslime kiralanmıştır ${ }^{104}$. Mezkûr arazi 1270/1853-54 yılına kadar aynı minval üzere ve aynı rakamlarla kiralanmaya devam edilmiştir ${ }^{105}$.

10-Eyüp Otakçılar'da su teşkilatı olan bahçe,

Bu arazi aylık 150 kuruş kira ile 1264/1847-48 senesinde Seyyid Ali ibn Hüseyin'den kızları Şerife Ayşe, Şerife Nesibe ve Vesile hanımlara intikal etmiştir ${ }^{106}$.

97 BOA, EV, 38215, vd. 17b.

98 BOA, EV, 38215, vd. 17b.

99 Bu köy bugün Esenler sınırındaki Atışalanı civarıdır. http://www.esenler.gov.tr/tarihce erişim tarihi 8.6.2021.

100 BOA, EV, 38215, 14b.

101 BOA, EV, 38215, vr. 18b-19a.

102 BOA, EV, 38215, 9b.

103 BOA, EV, 38215, 19b/2.

104 BOA, EV, 38215, 5a.

105 BOA, EV, 38215, 5a.

106 BOA, EV, 38215, 10a. 
11-Cağaloğlu Hoca Rüstem Mahallesi'nde dört dükkân ve dükkânlara bitişik 510 zira arsa üzerinde bir ev,

Saliha Sultan bu gayrimenkul için vakfiyede mülküm ifadesini kullanmamış olsa da sonraki dönemlerde mezkûr arazi vakıf akarları arasında zikredilmiştir. Örneğin, 1249/183334 senesinde bu ev ve diğer akarlar Nimetullah Hanım ibn İbrahim'in tasarrufundan olup, aylık kirası 180 kuruştur ${ }^{107}$. Bu kayıttan hareketle Saliha Sultan'ın vakfettiği bu arazinin de mülk olduğunu kabul etmek akla yatkın ihtimaldir.

12-Şehremini Koruk Mahmud Mahallesi'nde 1.023 zira arsa üzerinde ev ve bahçe,

1.023 zira büyüklüğünde olan bu arsada bir köşk, müştemilatı ve bahçe bulunmaktadır. Akar daha Saliha Sultan hayatta iken ve 27 Muharrem 1190/18 Mart 1776 tarihinde vakfedildikten hemen sonra 23 Rebiyülevvel 1190/12 Mayıs 1776 tarihinde vakıf olması sonrasında hüccet ile 500 kuruş ve yevmi 1 akçe ile yine Ahmed Efendi'ye kiralanmıştır ${ }^{108}$. Bu ifadeden arazinin vakıf olduğu, icareteyn ile Ahmed Efendi'ye verildiği, onun da üzerine yapılan köşk ve müştemilatını inşa edip mülkiyetini tescil ettirdiği, ancak arsa kirasını vakfa vermeye devam ettiği anlaşmaktadır. Ahmed Efendi 1199/1784-85 tarihinde ise kiralamadan feră ederek haklarının el-Hac Osman ibn Mehmed'e 130 kuruş mukabelesinde devretmiştir ${ }^{109}$.

13-Hoca Rüstem Mahallesinde otuz sekiz zira arsada bir hekim dükkânı ${ }^{110}$.

Son olarak zikrettiğimiz bu akar ile alakalı sonraki dönem muhasebe kayıtlarında bilgi bulunmamaktadır. Kayıtta görüleceği üzere Sultanahmet Camii civarında küçük bir dükkân olan bu gayr-i menkul sonraki dönemlerde ya yıkılmış ya da başka bir gayr-i menkule eklenmiş olmalıdır.

Saliha Sultan'ın akar olarak tahsis ettiği gayr-i menkullere bakıldığında, yukarıda zikrettiğimiz üzere ilk iki akarın babasının kendisine temlik ettiği araziler olduğu görülmektedir. Sonraki akarlardan üçü Küçükçekmece'de, biri Beyazıt'ta, biri Eyüp’te, biri Şehremini'nde, ikisi Cağaloğlu'nda, biri Kasımpaşa'dadır. Yani vakıf akarlarından beşi hariç hepsi sur içi İstanbul'unda bulunmaktadır. Saliha Sultan ilk üç akar dışındakileri büyük ihtimalle satın almıştır.

\section{d. Vakfın Osmanlı’nın Son Dönemindeki Akar ve Hayratı}

Saliha Sultan vakıfları mevcudiyetini, başlangıçta tesis edilen yönetim sistemi, soyunun devam etmesi ve mütevellilerin akarları takip etmekteki hassasiyeti gibi saiklerle Osmanlı

107 BOA, EV, 38215, 5a.

108 Kanaatimizce yukarıdaki tarihte el-Hac Ali Efendi'ye yapılan kiralama süresi bitmiş, bu tarihte yevmi 1 akçeye yeniden aynı şahsa kiralanmıştır (EV, 38215, vr. 14a).

109 BOA, EV, 38215, vr 14a.

110 VGMA, 741, s. 249, sira 142. 
Devleti'nin sonlarına hatta Cumhuriyet dönemine kadar muhafaza ettirebilmiştir. $\mathrm{Bu}$ minvalde 1329/1911 ve 1333/1915 yıllarında o dönemin Mütevellisi Şerife Feride Hatun'un nezaretinde tutulmuş olan akar ve hayratın muhasebesi şöyledir:

\begin{tabular}{|l|l|}
\hline Tablo 4: Saliha Sultan Vakıfları'nın 1329-1333/1911-1915 yılları akarları \\
\hline Adı & Geliri (yıllık) \\
\hline Göksu'da icare-i vahideli 1 bahçe & 1.000 kuruş \\
\hline Göksu'da icare-i vahideli 2 bahçe & 275 kuruş \\
\hline Göksu'da çayır kirası & 200 kuruş \\
\hline Göksu'da mera kirası & 150 kuruş \\
\hline Küçükçekmece'de tarla ve bağ kirası & 350 kuruş \\
\hline Küçükçekmece'de akar kirası & 35 kuruş \\
\hline Göksu'daki arazilerin artan mukataa gelirleri & 4.570 kuruş \\
\hline $\begin{array}{l}\text { Ayestefanos'da Rus Devletinin inşa ettiği manastır arazi kirasi }{ }^{111} 1325 / 1907-08 \\
1329 / 1911\end{array}$ & $\begin{array}{l}564 \text { kuruş } \\
528 \text { kuruş }\end{array}$ \\
\hline Göksu'daki Bostanın \%10 genişletmeden elde edilen geliri & 780 kuruş 39 para \\
\hline Toplam & $\mathbf{8 . 4 5 2}$ kuruş $\mathbf{3 9}$ para ${ }^{112}$ \\
\hline
\end{tabular}

Bu muhasebeye ilaveten doğrudan vakfin kasasında bulunan Rus manastırının 1326/190809 ve 1327/1909-10 yıllarından kira geliri 1.128 kuruş, Göksu bostanının 1327/1909-10 yılından kira geliri 832 kuruş 20 para, 1329/1911 y1lı toplam geliri 10.413 kuruş 59 para olarak tahakkuk etmiştir ${ }^{113}$.

Ayrıca liste incelendiğinde bu tarihte vakıf akarlarından sadece Göksu ve Küçükçekmece'deki mülklerin gelirlerinin muhasebeye yansıdığı; Eyüp, Kasımpaşa ve Suriçi'nde bulunan akarların ise yansımadığg görülmektedir. Bu konuda aklımıza gelen ilk husus Saliha Sultan'ın 1190/1776-77 yılında tesis ettiği üç, 1192/1778-79 yılında tesis ettiği bir vakfında kethüdası ve vakfın mütevellisi olarak kaydedilen Ali Bey'in 27 Muharrem 1190/18 Mart 1776 ve 27 Muharrem 1192/25 Şubat 1778 tarihlerinde Saliha Sultan'a vekâleten tanzim ettirdiği iki vakfiyesinin akar ve hayır şartlarındaki farklılık gelmektedir. Şöyle ki, 1190/1776-77 tarihli vakfiyede dokuz değişik akar sayılmış ve bunlardan elde edilen

111 Malum olduğu üzere Osmanlı Devleti, tarihlerimize 93 harbi olarak geçen 1876 yılındaki savaşta Rusya’ya karşı ağır bir yenilgi almış ve savaşın ardından Ruslar bugünkü Bakırköy’e kadar ilerlemişlerdir. Bu çalışmanın konusunu ilgilendiren husus bu savaşta o günkü taksimde Küçükçekmece Kazası'nda cereyan eden cephede ölen Rus askerleri için inşa edilen mezarlık ve bu çevreye yapılan manastırın Saliha Sultan vakfı arazisine inşa edilmesidir. Dönemin vakıf hukuku gereği Saliha Sultan vakıflarına yıllık 500 kuruş üzerinde kira ödenmiştir. Bu alana yapılan anıt ve manastır 1914 yılında yıkılmıştır. https://www.turkyurdu.com.tr/ yazar-yazi.php?id=3770 (erişim tarihi 26.6.2021); https://kulturenvanteri.com/yer/ayastefanos-rus-abide si/\#16.59/40.983434/28.788457 (erişim tarihi 26.6.2021).

112 VGMA, 1829, 24/9, s. 8; 1835/1, s. 6.

113 VGMA, 1829, 24/9, s. 8. 
gelirlerin bundan evvel tahsis edilen hayır alanlarına harcaması istenmiştir ${ }^{114}$. Ardından Safer ayında bu vakıflara iki ek daha yapılmıştır. 1192/1778-79 tarihinde tesis edilen vakfiyede ise akar olarak 7 adet akar sayılmış, hayır şartı olarak ise 27 Muharrem 1190/18 Mart 1776 vakfiyesinden farklı olarak aşağıda listelediğimiz 7 adet akarın gelirlerinin tamamıla evladiyet üzere tahsisi istenmiştir ${ }^{115}$. Yani bu tasarruf ile aşağıdaki akarların gelirleri Saliha Sultan'ın 1151/1738-39'den 1190/1776-77 yılına kadar tesis ettiği vakıf hayratından çıkarılmış ve evladına tahsis edilmiştir.

1- İstanbul Mahmutpaşa Cezeri Kasım Paşa Mahallesi'nde üç yüz otuz zira arsa üzerinde 3 katlı müştemilatı olan bina ve bahçesi,

2- Küçükçekmece'de iki katlı ev ve bahçesi,

3- Küçükçekmece kumsalda üzüm bağı ve bahçe,

4- Kasımpaşada Yeldeğirmeni Mahallesi'nde 2.591 zira arazide evler ve bahçeler,

5- Eyüp Otakçılar'da su teşkilatı olan bahçe,

6- Cağaloğlu Hoca Rüstem Mahallesi’nde 4 dükkân ve dükkânlara bitişik 510 zira arsa üzerinde müştemilatlı bir ev,

7- Hoca Rüstem Mahallesi'nde otuz sekiz zira arsada bir hekim dükkân11 ${ }^{116}$.

Görüldüğü üzere Saliha Sultan'a vekâleten 1192/1778-79 tarihinde son vakıf uygulamasını gerçekleştiren Ali Bey ibn Yahya Paşa yukarıdaki yedi akarı diğer altı akardan ayırmış ve bunları evlatlık yapmıştır. Oldukça ilginç bir uygulama olan bu tasarrufun sebebi kanaatimizce Ali Bey’in Saliha Sultan tarafından vakfedilen ve muhtemelen babası Yahya Paşa kaynaklı olabilecek akarlarının tasarrufunu diğer altı akardan ayırmasıdır ${ }^{117}$. Belki de bu nedenle yukarıda saydığımız akarlar aşağıda görüleceği üzere vakıf muhasebelerine yansımamıştır.

Günümüz itibarıyla vakfın kadimden gelen İstanbul Göksu ve Kandilli sınırlarında kalan bir kısım akarları ile daha sonra mütevelliler tarafından satın alındığını düşündüğümüz Kartal'daki iki dairesi bulunmaktadır ${ }^{118}$.

\section{e. Hayır Şartları}

Saliha Sultan zengin sayılabilecek hayratından büyük veya küçük herhangi bir yapı inşa etmemiştir. Daha çok İstanbul camilerinde yürütülmesini arzu ettiği bazı eğitim faaliyetleri,

114 VGMA, 741/s. 549, sira 142.

115 VGMA, 747, s.113, sira 109.

116 VGMA, 741, s. 249, sira 142.

117 VGMA, esas no: 737/336-337. Vakıflar Genel Müdürlüğü tercümanı Hatice Hatun’un Fatma Hanım'ın kızı Emine Hatun'un çocuğu olduğunu kaydetmiştir. Bu durumda Fatma Hanım’ın kızı Emine Hatun Ali Bey ile evlenmiş olmalıdır.

118 Çalışmalarımız esnasında son dönem belge ve bilgilerin temini ve vakfın güncel durumu hakkında yardım ve ilgilerini esirgemeyen Vakıflar Genel Müdürlügü Kültür ve Tescil Daire Başkanı Mevlüt Çam Bey ile İstanbul Vakıflar II. Bölge Müdürlüğü Vakıf Hizmetleri ve İntifa Şubesinden Sevinç Salebci Hanım’a teşekkürü bir borç biliriz. 
vefat edenin ruhuna Kur'an okuma ve vazifelilere tahsisat yapmıştır. Bu minvalde ilk vakfını tesis ettiği 1151/1738 tarihinde yukarıda zikri geçen akarlardan elde edilecek gelirlerle şu hayırların yapılması istenmiştir.

\begin{tabular}{|c|c|c|}
\hline Vazife & İşi & Para (Akçe) \\
\hline Vaiz & Sultan I. Selim Camii’nde haftada bir gün vaaz ve nasihat etmek & 20 \\
\hline Müderris & Sultan II. Mehmed Camii'nde her gün ulum-i nafia tedris ettirmek & 20 \\
\hline Müderris & Piri Paşa Câmii'nde her gün ulum-i nafia tedris ettirmek & 20 \\
\hline Kurra & Eyüp Sultan Türbesi'nde isteyene Kur'an okutmak & 20 \\
\hline Seccadeci ve kayyım & Eyüp Sultan Camii kayyımı & $1+1$ \\
\hline Kâtip & Nakit ve taamiye eşit olarak & $8+8^{119}$ \\
\hline Câbi & & $4+5$ \\
\hline İmam ve hatip & Yabanabad (Kızılcahamam) Bükeler Köyü ${ }^{120}$ Hacı Mustafa Camii & 10 \\
\hline Müezzin & Yabanabad (Kızılcahamam) Bükeler Köyü Hacı Mustafa Camii & 5 \\
\hline Tamirat & Yabanabad (Kızılcahamam) Bükeler Köyü çeşmesinin su yolunun tamiri & 5 \\
\hline Vakıf Nazırı & Yabanâbaddaki (Kızılcahamam) işlemleri takip etmek & 10 \\
\hline Mütevelli & & 20 \\
\hline Toplam 11 vazifeli & & $140^{121}$ \\
\hline
\end{tabular}

Görüldüğü üzere Saliha Sultan bu vakfiyesinden yukarıda zikrettiğimiz akarlardan elde edilecek kira gelirlerinden toplam 140 akçeyi nazır ve mütevelli de dâhil olmak üzere on iki cihete hasretmiştir. Bunlardan altı tanesi ihtisas hizmeti dediğimiz müderrislik, vaizlik, imamlık ve müezzinlik cihetleri için tahsis edilmiştir. Saliha Sultan dört camide vaaz, tedris ve Kur'an kıraati için tahsisat yapmıştır. Bunlardan Eyüp Camii ve Türbesi'ne olan ilgisine vefatı dolayısı ile detaylı olarak değindiğimizden burada Sultan Selim, Sultan II. Mehmed ve Piri Paşa Camilerine olan tahsisatına temas etmek istiyoruz.

Kanaatimizce Saliha Sultan zaman zaman Eyüp Sultan Camii dişında Sultan Selim, Fatih ve Piri Paşa Camilerine ziyaret veya namaz kılmak üzere gitmektedir. Bu ziyaretleri esnasında dönemin teamülü gereği buralarda halen devam eden ve önceden var olup bir sebeple kesintiye uğramış veya uğrayacak bazı tedris faaliyetlerini devam veya ihya etmek istemiş olmalıdır. Ya da kadı veya kethüdası vasıtasıyla bu camilerde yaptığ 1 tahsise yönelik

119 Karşılaştırınız 1151 ve 1190 tarihli vakfiyeler.

120 Hâlihazırda yaptığımız tetkiklerde Kızılcahamam ve çevresinde bu isimle bir köy bulunmamaktadır. Ancak Bükeler Köyünde 1078/1667-68 tarihinde Mustafa adlı bir hayırseverin camii yaptırma talebi Yabanabad Kadısı tarafından Sultan'a arz edilmiştir. (BOA, İE.EV, 836) bu bilgiden hareketler vakfiyede açık olarak

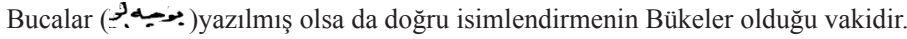

121 Görevlerin genel değerlendirmesi için bkz. Juliette Dumas, Les perles de nacre du sultanat Les princesses ottomanes (mi-XVe - mi-XVIIIe siècle), École des Hautes Études en Sciences Socrales École Doctorale d'histoire Et Civilisations, Thèse de Doctorat Inédite, Paris 2013, s. 767-768. 
bir ihtiyacın olduğu kendisine ulaştırılmış, Saliha Sultan da vakfından mezkûr tahsisleri yapmış olabilir.

Saliha Sultan'ın dikkat çeken diğer tahsisatı kâtip ve câbi için yapmış olduğu tayin ve değiştirmesidir. 1151/1738-39 tarihli vakfiyesinde câbi ve kâtibin aynı kişide toplanmasını ve toplam sekiz akçe günlük almasını istemiştir ${ }^{122}$. 27 Safer 1190/17 Nisan 1776 tarihli vakfiyesinde ise bu şartı değiştirerek kâtibe sekiz akçe nakit ve sekiz akçe taamiye ${ }^{123}$, câbiye ise beş akçe vazife ve dört akçe taamiye tahsis etmiştir ${ }^{124}$. 1242/1826-27 tarihinde Vakıf kâtibi ve câbisi es-Seyyid İbrahim Efendi ibn Veli'dir. Vakıf şartında belirlenen 16+9 akçe yevmiyesi devam etmektedir ${ }^{125}$. 1294/1877-78 y1lına gelindiğinde ise Vakfın mütevellisi olan Şerife Zeynep Hanım Evkaf Nezareti'ne bir takrir yazarak büyük annesi Saliha Sultan'ın kâtip ve câbi için tahsis etmiş olduğu yevmiye ile taamiyelerin kâfi gelmediğini, yaklaşık 100 yıl evvel tayin edilen meblağlar ile hakkıyla hizmet edilemeyeceğini belirtmiştir. Çare olarak da vakfın 1293/1876-77 yılı fazlalarından senelik 3.000 kuruşun kâtip ve câbiye tahsisini teklif etmiştir. Ariza kabul edilmiş neticede önceki vakfiyede belirlenen meblağa on altı akçe kâtiplik dokuz akçe câbilik olmak üzere toplam 25 akçe yani iki katı oranında artış yapmıştır (9 Cemaziyelahir 1294/21 Haziran 1877) ${ }^{126}$.

\section{f. Yabanabad (Kızılcahamam) Tahsisleri ve Şartın Değişmesi}

Saliha Sultan'ın tesis ettiği ilk vakfiyesinde dikkat çeken en mühim husus bugünkü Kızılcahamam'da bulunan Bükeler (Bucalar) Köyü Camii ve su tesisine yapmış olduğu tahsisattır. Bu tasarrufun temelinde Saliha Sultan'ın yanında bulunan kişilerden birinin bu köyden olduğu veya kendisine ulaşan bir bilgiden hareketle Bükeler (Bucalar) köyüne tahsisat yaptığını düşünebiliriz ${ }^{127}$. Saliha Sultan ilk vakfiyesinden bir süre sonra mezkûr tahsisini değiştirmiş ve şu vazifeleri ihdas etmiştir:

\begin{tabular}{|l|l|l|}
\hline \multicolumn{2}{|l|}{ Tablo 6: Yabanabad (Kızılcahamam) Şartları Yerine İhdas Edilen Vazifeler } \\
\hline Mekân & İsii & Parası \\
\hline İstanbul Koca Mustafa Paşa Camii & Vaiz şeyh Mustafa Efendi'ye her Cuma vaaz etmesi mukabilinde & 20 akçe \\
\hline Koca Mustafa Paşa Camii & Seccadeci & 5 akçe \\
\hline
\end{tabular}

Vakfiyede Saliha Sultan'ın bu değişikliği neden yaptığına dair bir izahat yer almamaktadır. Kanaatimizce ilk yıl yapılan muhasebe sonunda belki uzak bir hayrata 20 akçe tahsisatın

122 VGMA, 736, s. 77, sira 27/1.

123 Günlük yemek ücreti.

124 VGMA, 736, s. 77, sira 27/2.

125 VGMA, 36/66, s. 146.

126 BOA, EV, 38215, 2a, defterdeki kuruş akçe hesabı iki kat alındığından bir kuruşun 3 akçeye denk geldiği görülmektedir.

127 VGMA, 736, s.77, sira 27/1. 
gönderilme zorluğu, belki de ihtiyaç kalmaması gibi sebeplerden dolayı yukarıdaki değişiklik yapılmıştır ${ }^{128}$.

İkinci vakfiyesindeki değişiklikten 28 yıl sonra Saliha Sultan 21 Safer 1990/11 Nisan 1776 tarihinde yine ilk vakfiyesindeki akarlara İstanbul Bayezid Soğanağa Mahallesi’nde üç katlı ve bahçeli bir evin kira gelirlerini ekleyerek, aşağıdaki şartları eklemiştir ${ }^{129}$.

\begin{tabular}{|l|l|l|}
\hline \multicolumn{2}{|l|}{ Tablo 7: İstanbul Bayezid Soğanağa Mahallesi Gelirlerinden Yapılan Hayrat Şartları } \\
\hline Vazifeli & Vazife & Para \\
\hline Abdullah Efendi & $\begin{array}{l}\text { Eyüp Sultan Türbesi'ndeki Hz. Peygamber'in ayak izinin önünde perşembe } \\
\text { günü ikindi namazı öncesi isteyenlere Delâil-i Hayrat okutması }\end{array}$ & 30 akçe \\
\hline Abdullah Efendi & Eyüp Camii’nde haftada bir gün ikindi namazı sonrası vaaz etmesi & 30 akçe \\
\hline Minderci ${ }^{130}$ & Cami ve türbede ders dinlerken minder sermesi & 3 akçe \\
\hline Veliyyüddin Efendi ${ }^{131}$ & Sultan Ahmed Türbesi’nde haftada iki gün talibine ulum-i nâfia okutmas1 & 60 akçe \\
\hline Minderci & Sultan Ahmed Türbesi'nde cemaate minder sermesi & 4 akçe \\
\hline Toplam & $\mathbf{5 ~ v a z i f e ~}$ & $\mathbf{1 2 7}$ akçe \\
\hline
\end{tabular}

Saliha Sultan bu vakfiyesinde de yeni bir hayrat bina etmemiş, bir önceki vakfiyesine benzer şekilde Eyüp Sultan Camii'ne daha evvelki hayratından başka türbede ve camide vaaz edilmesi ve Delâil-i Şerif okunması için toplamda 60 akçe, bu ameliyeleri takibe gelenlere hizmet edecek vazifeliye ise günlük üç akçe tahsis etmiştir. Sultan Ahmed Camii’nde tedris vazifesi yapacak olan Veliyyüdin Efendi'ye verilen meblağ ise vakıf giderleri arasında en yüksek tahsisat olma özelliğine sahiptir.

Saliha Sultan 4 Rebiyülevvel 1190/23 Nisan 1776 tarihinde Ehl-i Kur'an bir kimsenin günlük sekiz akçe karşılığında, kendisi tarafından Eyüp Camii'ne vakfedilen Kur'an-ı Kerim'den her gün bir cüz okumasını, ayda bir hatmi tamamlayıp müezzin mahfelinde duasını yapmasını ve annesi Hatem Hatun'un (Hacce Hanım) ruhuna hediye etmesini istemiştir. Aynı şekilde Ayasofya Camii'nde de ehl-i Kur'an birinin her gün bir cüz okumasını ve müezzin mahfelinde ayın son Cuma'sında hatmi bitirip duasını yapmasını şart etmiştir ${ }^{132}$.

Görüldüğü üzere Saliha Sultan tayin ettiği on üç akardan elde edilen kiralar ile 20 vazifeli tayin ederek bunlara günlük 228 akçe tahsis etmiştir. Bu rakamın yıllık muhasebesi kameri yıl hesabıyla 80.712 akçeyi bulmaktadır.

Vakfiyeleri bu şekilde zikrettikten sonra takip etmemiz gereken önemli bir husus hayratın sonraki yıllarda nasıl devam ettiği veya ne şekilde dönüştüğü sorularına cevap aramak

128 VGMA, 739, s. 235, sira 139.

129 VGMA 741, s. 50, sira 143.

130 Cami veya türbelere ibadet veya ziyaret maksadıyla gelenlerin oturmaları için minder koyup toplayan kişi.

131 VGMA, 736, s. 77, sira 27/2.

132 VGMA,741, s. 251, sira 144. 
olacaktır. Yukarıda da temas ettiğimiz üzere Saliha Sultan akarlarının biri haricinde tüm gelir getiren gayr-i menkuller için “mülküm” ifadesini kullanmıştır. Bu ifadeden 1192/1778 tarihli son vakfiyede tamamen evlada tahsis edilen akarların haricindeki gelir kaynaklarının, sonraki dönemlerde aşağıda zikredeceğimiz hayrata aktarılmış olduğunu söylemek mümkündür. $\mathrm{Bu}$ minvalde vakfın kuruluşundan sonra muhasebelere yansıyan hayır şartları şöyledir:

\begin{tabular}{|c|c|c|}
\hline Vazife & Tarihi & Tahsis Edilen Para \\
\hline $\begin{array}{l}\text { Eyüp Sultan Câmii'nde Saliha Sultan'ın annesi için } \\
\text { Kur'an okuyacak Hafız Tahir Efendi ibn Mustafa'ya }\end{array}$ & $1225 / 1810-11$ & 7 kuruş ${ }^{133}$ \\
\hline $\begin{array}{l}\text { Eyüp Câmii’nde Delâil-i Hayrat muallimi Hafiz Halil } \\
\text { ibn Hacı İbrahim'e }\end{array}$ & $1225 / 1810-11$ & Vakfiyedekimeblağ $^{134}$ \\
\hline Eyüp Câmii'nde minderci Veliyüddin ibn Halil'e & $1225 / 1810-11$ & Vakfiyedeki meblağ \\
\hline Eyüp Camii Şeyhü'l-Kurrası Hafız Ahmed Efendi'ye & $1225 / 1810-11$ & 6,5 kuruş \\
\hline $\begin{array}{l}\text { Eyüp Camii imam ve vaizi es-Seyyid el Hac Mustafa } \\
\text { Efendi ibn Mehmed Efendi’ye }\end{array}$ & $1236 / 1820-21$ & -135 \\
\hline $\begin{array}{l}\text { Sultan Ahmed Câmii'ndeki Ankaravî Mustafa Efendi ibn } \\
\text { Mustafa'ya }\end{array}$ & $1240 / 1824-25$ & 6 kuruş $^{136}$ \\
\hline $\begin{array}{l}\text { Koca Mustafa Paşa Câmii'ndeki vaiz Hafız Ali Efendi } \\
\text { ibn el-Hac İbrahim'e }\end{array}$ & 17 Safer 1246/7 Ağustos 1830 & 6,5 kuruş \\
\hline Koca Mustafa Paşa Câmii'ndeki seccadeciye & 17 Safer $1246 / 7$ Ağustos 1830 & 1 kuruş $^{137}$ \\
\hline Piri Paşa Câmii'nde tayin edilen müderris ve seccadeciye & 17 Safer $1246 / 7$ Ağustos 1830 & 6 kuruş? ${ }^{138}$ \\
\hline Ayasofya Camii müezzini Abdullah Efendi’ye & 17 Safer $1246 / 7$ Ağustos 1830 & 6 kuruş $^{139}$ \\
\hline Sultan Selim Camii vaizi Hafız Mustafa ibn Hüseyin'e & $1236 / 1820-21$ & 6,5 kuruş $^{140}$ \\
\hline
\end{tabular}

Listede görüldüğü üzere vakıflar idaresindeki köklü değişim döneminde, Saliha Sultan hayırlarının büyük ölçüde devam ettiği, hatta yukarıda zikredilmese de Kızılcahamam'daki üç şartın da kaydedildiği ancak vakfiyelerin incelenmesinden sonra iptal edildiği vakidir.

Osmanlı Döneminde vazifeler ile alakalı son kayıtlar Birinci Dünya Savaşı'ndan hemen önce tutulmuştur. 1329/1911 ve 1333/1915 yıllarında detayını verdiğimiz gelirlerden harcanan para miktarları ise şöyledir:

133 VGMA, 36/66, s. 146.

134 VGMA, 36/66, s. 147.

135 Vakfiyede 30 akçe olarak tahsis edilmiş olan bu akarın 1236/1820-21 yılındaki rakamı belge üzerindeki aşınmadan dolayı tespit edilememiştir (VGMA, 36/66, s. 147).

136 VGMA, 36/66, s. 146.

137 VGMA, 36/66, s. 146.

138 VGMA, 36/66, s. 147.

139 VGMA, 36/66, s. 146.

140 VGMA, 36/66, s. 147. 


\begin{tabular}{|c|c|c|c|}
\hline Görev & $1329 / 1911$ & $1333 / 1915$ & Vazifeli Adı \\
\hline Tevliyet & 20 Kuruş & 60 kuruş & $\begin{array}{l}\text { Zeynep Hanım binti Salih } \\
\text { Bey }\end{array}$ \\
\hline Kitabet (maaş ve taamiye) & 48 & 36 & $\begin{array}{l}\text { Esseyyid Mehmed Azmi } \\
\text { Efendi ibn Mehmed Arif }\end{array}$ \\
\hline Câbilik (maaş+taamiye) & 27 & 39 & $\begin{array}{l}\text { Esseyyid Mehmed Azmi } \\
\text { Efendi ibn Mehmed Arif }\end{array}$ \\
\hline Sultan Selim Câmii'nde vaiz & 60 & 60 & \\
\hline Sultan Selim Câmii'nde seccadeci & 3 & 3 & \\
\hline Eyüp Câmii'nde Hafiz-1 Kur'an & 60 & 60 & $\begin{array}{l}\text { Es Seyyid Hafız Mustafa } \\
\text { Rakım Efendi }\end{array}$ \\
\hline II. Mehmed Câmii'nde müderris & 60 & 60 & \\
\hline I1. Mehmed Câmii'nde seccadeci & 3 & 3 & \\
\hline Ayasofya Câmii'nde cüz okuyucu & 60 & 60 & \\
\hline Ayasofya Câmii'nde seccadeci & 3 & & \\
\hline Piri Mehmed Paşa Câmii'nde müderris & 60 & 60 & \\
\hline $\begin{array}{l}\text { Eyüp Câmii'nde Delâil-i Hayrat okutacak } \\
\text { müderris }\end{array}$ & 90 & 90 & \\
\hline $\begin{array}{l}\text { Diğer ders hayırları Valide Sultan } \\
\text { Türbesi'nde }\end{array}$ & & $180^{141}$ & \\
\hline İmza harcı & 5 & 2 & \\
\hline Koca Mustafa Paşa Câmii'nde vaiz & & 60 & \\
\hline Koca Mustafa Paşa Câmii'nde seccadeci & & 3 & \\
\hline Sultan Osman Câmii'nde vaiz ${ }^{142}$ & & 36 & \\
\hline Kızılcahamam Bükelerde kitabet ve cibayet & 8 akçe & & $\begin{array}{l}\text { Esseyyid Mehmed Azmi } \\
\text { Efendi ibn Mehmed Arif }\end{array}$ \\
\hline Toplam & $\begin{array}{l}14 \text { vazife } 668 \\
\text { kuruş }^{143}\end{array}$ & $\begin{array}{l}16 \text { vazife } 937 \\
\text { kuruş }^{144}\end{array}$ & \\
\hline
\end{tabular}

1329/1911 y1lı muhasebesi neticesinde akarlardan elde edilen meblağdan masraflardan arta kalan 7.380 kuruş 19 para Saliha Sultan'ın evladı arasında taksim olunmuş, 404 kuruş 20 para hazine payı ayrılmıştır ${ }^{145}$. Yukarıdaki muhasebe kayıtlarında özellikle 1333/1914-15 yılında iki vazifenin vakıf giderlerine eklendiği görülmektedir. Bu fazlalığın vakfiyede yer alan Sultan Ahmed Camii hayırlarının mütevelli marifetiyle değiştirildiği düşünülebilir.

141 VGMA, 1835/1, s. 6, daha evvelki şartlarda olmamasına rağmen 1333/1914-15 tarihinde mütevelli marifetiyle hayrat şartlarına dahil edilmiştir.

142 VGMA, 1835/1, s. 6, bu vazifede bir önceki gibi 1333/1914-15 tarihinde mütevelli marifetiyle hayrat şartlarına dahil edilmiştir.

143 VGMA, 1829/24, s. 9.

144 VGMA, 1835/1, s. 6.

145 VGMA, 1829/24, s. 9. 


\section{Cumhuriyet Döneminde Saliha Sultan Vakıflarının Hayratı}

Osmanlı Vakıfları ile alakalı olarak Osmanlı döneminde yaşanan kimi olumsuz gelişmelerden başka Cumhuriyetin ilanından sonra, özellikle Saliha Sultan vakfındaki hayır şartları gibi camilerde gerçekleştirilen tedris ve kıraat faaliyetlerinin ciddi bir değişime uğradığı, hatta ifa edilmeme gibi bir duruma evirilmiş olduğu muhakkaktır. Çünkü 1924 yılından itibaren Saliha Sultan Vakıfları gibi az sayıdaki vakıf mülhak olarak kabul edilmiş ve mütevellisi tarafindan idare olunmaya devam etmiştir. Resmi uygulama böyle olsa da gerek akarlarının farklı sebeplerle ortadan kalkması, gerekse hayır şartlarının yerine getirilememesi nedeniyle, kimi vakıfların gelir ve harcamaları Vakıflar Genel Müdürlüğü tarafından genelde farklı alanlara yönlendirilmiştir. Bu doğrultuda Vakıflar İdare Meclisi 13.09.1945 tarihinde bir karar almıştır. Karara göre Saliha Sultan Vakıfları hala mütevellisi tarafından idare edilmektedir. Ancak yukarıda temas edildiği üzere vakfiyelerde zikredilen hayır şartları tam olarak yerine getirilmediğinden öncelikle Vakıf Gureba Hastanesi'ne tevcih edilmesi gündeme gelmiş ancak, o gün için ortalama geliri 390 lira olan altı vaizlik ve iki cüzhanlık hizmetlerinin aktarılmasının uygun olmayacağı kanaati hâsıl olmuştur. Neticede yerine getirilemeyen vazifeler ile yerine getirilen vazifeler birleştirilmiş, Ayasofya Camii şartının da başka bir camide uygulanmasına karar verilmiştir ${ }^{146}$.

Karara göre yapılamayan ve yapılan hizmetlerin birleştirilmesi şöyle olmuştur.

\begin{tabular}{|l|l|}
\hline Tablo 10: Birleştirilen Vakıf Hizmetleri \\
\hline Yapılamayan & Yapılıp birleştirilen \\
\hline Eyüp Sultan Türbesi’nde Delâil-i Şerif okunması şartı & Sultan Selim Camii vaizlik \\
\hline Sultan II. Ahmed Türbesi dersiamlık & Sultan Ahmed Camii vaizi \\
\hline Sultan II. Ahmed Türbesi mindercilik & Eyüp Camii vaizlik \\
\hline Câbiye verilen taamiye & Eyüp Camii cüzhanlık \\
\hline Kâtip taamiye & Ayasofya Camii cüzhanlık ${ }^{147}$ \\
\hline Nezaret, cibayet & Mütevellilik $^{148}$ \\
\hline
\end{tabular}

29.11.1945 tarihinde ise yukarıdaki hizmetlerden kâtiplik ciheti zikredilmediğinden bu vazifenin de mütevellilik ile birleştirilmesi kararı çıkmıştır ${ }^{149}$.

Bu kararlardan sonra 05.01.1946 tarihinde Saliha Sultan vazifelerinde şöyle bir denkleştirme yapılmıştır:

146 VGMA, 1965, s. 96, sira 109.

147 Kararın biraz üstünkörü alındığı görülmektedir; çünkü kararın başlangıcında Ayasofya Câmii'nde zaten yapılamayan cüzhanlık hizmetine başka bir birleştirme yapılması bu dönemde vakıf hukuku noktasındaki özensizliği gözler önüne sermektedir.

148 VGMA, 1965, s. 96, sira 109.

149 VGMA, 1965, s. 118, sira 136. 


\begin{tabular}{|c|c|c|c|c|c|}
\hline \multirow{2}{*}{\begin{tabular}{|l} 
Vazife \\
Sultan Osman Câmii'nde vaiz ${ }^{150}$ \\
\end{tabular}} & \multirow{2}{*}{$\begin{array}{l}\text { Vakfiyede } \\
\text { Akçe } \\
12 \\
\end{array}$} & \multicolumn{2}{|c|}{$\begin{array}{l}\text { Yeni } \\
\text { Lira Kuruş }\end{array}$} & \multicolumn{2}{|c|}{$\begin{array}{l}\text { Tahsisat } \\
\text { Lira Kuruş }\end{array}$} \\
\hline & & 3 & 60 & 8 & 40 \\
\hline Sultan Selim Camii vaizi & 50 & 6 & & 35 & \\
\hline Sultan Selim Camii seccadeci & 1 & & & & 70 \\
\hline Sultan Mehmed Camii vaiz & 80 & 6 & & 56 & \\
\hline Sultan Mehmed Camii seccadeci & 1 & & & & 70 \\
\hline Piri Paşa Camii vaiz & 20 & 6 & & 14 & \\
\hline Piri Paşa Camii seccadeci & 1 & & & & 70 \\
\hline Eyüp Camii kurra & 20 & 6 & & 17 & \\
\hline Eyüp Camii seccadeci & 1 & & & & 70 \\
\hline Koca Mustafa Paşa Camii Cuma vaizi & 20 & 6 & & 14 & \\
\hline Koca Mustafa Paşa Camii seccadeci & 1 & & & & 70 \\
\hline Eyüp Camii vaiz & 34 & 9 & & 23 & 80 \\
\hline Eyüp Camii minderci & 3 & & & 2 & 10 \\
\hline Eyüp Camii cüzhan & 12 & & & 8 & 40 \\
\hline Ayasofya Camii yerine başka bir camiide cüzhan & 14 & & & 9 & 10 \\
\hline Mütevelli & 43 & & & 30 & 10 \\
\hline Toplam & 313 & & & 219 & $10^{151}$ \\
\hline
\end{tabular}

Yukarıda birleştirmelerin yapıldığı dönemlerde vakfın akarlarının da halen faaliyette olduğu ve hayrat şartlarına tahsisat yapıldığı sonucu çıkmaktadır. Nitekim bunu doğrular mahiyette 1941-1942-1943 yıllarında gelirleri Vakıflar Genel Müdürlüğü kayıtlarına şöyle yansımıştır.

\begin{tabular}{|l|l|l|}
\hline Tablo 12: Vakfin 1941-1942-1943 Yıllarındaki Gelirleri \\
\hline Yıl & Toplam Gelir Lira & Kuruş \\
\hline 1941 & 397 & 81 \\
\hline 1942 & 396 & 68 \\
\hline 1943 & 404 & $30^{152}$ \\
\hline
\end{tabular}

Cumhuriyet dönemindeki yönetim şu şekildedir: Vakfın Osmanlı dönemindeki son mütevellisi Feride Hanım'ın 1927 yılında vefatıyla tevliyet önce geçici olarak Yusuf Hüsnü Bey'e verilmiş, ardından muhtemelen Saliha Sultan'ın evladından olan Fatma Hanım'ın müracaatı ile ona intikal etmiştir ${ }^{153}$. Bu dönemde hanedanın yurt dışına çıkarılması

150 Bu vazife vakfiyelerde olmayı 1333/1914-15 tarihinde muhasebeye eklenmiştir.

151 VGMA, 1757, s. 313, sira 179.

152 VGMA, 1757, s. 314, sira 179.

153 VGMA, esas 120/1773. 
sonrasında, ikinci üçüncü dereceden akrabanın ön plana çıkmamaları ve belki de müracaatta bulunmamaları nedeniyle tevliyet intikali hemen gerçekleşmemiştir. Ancak Vakıflar idaresinin takibi veya haberleşmeler sonucunda Saliha Sultan'ın soyundan birinin bulunması sürecinde mütevelli kaymakamlarının atandığı görülmektedir. Bu minvalde 1934 yılında Hüsnü Bey’in vefatı sonrasında Kaymakamlığa Necmeddin Bey atanmıştır. Saliha Sultan'ın torunu Fatma Hanım'ın 1942 yılında vefatı sonrasında muhtemelen büyük oğlu Ahmed Fuad Öney vakfın yeni mütevellisi olmuştur. Ali Fuad Öney (v. 20.12.1950)'den sonraki mütevelliler ve atandıkları tarihler sırasıyla şöyledir:

Adviye Heybetullah Toker (v. 27.5.1963),

Saniye Altintoz (v. 3.6.1968),

M.Talat Önol (v. 12.11.1975),

Calibe Altıntoz (v. 6.10.2003) 154

Calibe Altıntoz'un vefatı sonrasında Vakıflar Genel Müdürlüğü Tevcih Komisyonu 11.9.2003 tarih ve 15 sayılı kararı ile vakfın emaneten yönetilmesine karar verilmiştir. $\mathrm{Bu}$ kararın ardından Köprülüzade Hafız Ahmed Paşa Vakfı Mütevellisi Emine Oya Bostan’ın mütevelli olarak atanması gündeme gelmiş, ancak o, işlerinin yoğunluğu nedeniyle Mehmet Kaya Çelikel'i tavsiye etmiştir. Komisyon yaptığı inceleme sonucunda 29.03.2006 tarihi itibarıyla mahkeme kararını da referans alarak mezkûr şahsın mütevelli olarak tayin edilmesine karar vermiştir. Halen vakfın mütevelliliği Mehmet Kaya Çeliker tarafından yürütülmektedir ${ }^{155}$. Kararda Mehmet Kaya Çeliker'in Saliha Sultan'ın evladından olup olmadığına dair bir kayıt bulunmamaktadır.

\section{Sonuç}

III. Ahmed'in hayatta iken arazi temlik ettiği, evlendirdiği ve kendisinden torunlarını gördüğü kızı olan Saliha Sultan, babasının vefatından sonra tahta geçen I. Mahmud, III. Osman, III. Mustafa ve I. Abdülhamid dönemlerinde yaşamıştır. Bu süreçte biri babası döneminde olmak üzere, toplam beş evlilik yapmış ve bu evliliklerden beş çocuğu doğmuştur.

Yaptığı evliliklerden dikkate değer mehir ve miras kalmış olsa da vefatı sonrası tespit edilen terekesi borçlarını ödemeye yetmemiştir. Bu husus da akla ya mal varlıklarının tamamını vakıflar ve mukataalar yoluyla yatırım ve gayr-i menkule dönüştürdüğü ya da son vakfiyesinde görüldüğü gibi Ali Bey tarafından bir şekilde çocuklarına kendi sağ iken intikal ettirdiği ihtimalini akla getirmektedir.

154 VGMA, esas 120/1773.

155 Vakıflar Genel Müdürlüğü tarafından oluşturulan mütevelli listesi incelendiğinde, bazı mütevellilerin vefatından sonra, diğer mütevellinin atanması hemen gerçekleşmemiştir. Bu aralıkta vakfın emaneten yönetilmesi kararı çıkmıştır. VGM, 29.3.2006, 16035/1 no.lu kararı. 
Hemen belirtelim ki, Saliha Sultan'ın muhallefâtından 25.386,5 kuruş 44 para elde edilmiş, masrafların 25.446 kuruş hesaplanmasıyla da 59 kuruşluk açık çıkmıştır. Vefatından sonra yapılan tespite göre, Saliha Sultan'ın üzerinde bulunan mukataaları: Aclun ve Leccun 16.300 kuruş, Biga 1.897.980 akçe, Girit zeytinyağı ve sabun 20.130 kuruş, Karahisar-i Şarki 3.800.700 akçe olarak tespit edilmiştir. Ancak muhallefât konusu çalışmanın hacmini fazla seviyede artıracağı ve muhtevası itibarıyla başka bir çalışmayı gerektirdiği için makaleye dahil edilmemiştir.

Çalışmamız sonucunda en mühim tespitlerimizden biri Saliha Sultan'ın evliliklerinin sayısının tam olarak ortaya çıkarılmasıdır. Gerek Sicill-i Osmanı̂'de gerekse yakın dönemde yapılan telif çalışmalarda dört evlilik yaptığı belirtilmesine rağmen, bu çalışma sonucunda Yahya Paşa ile evliliği açık bir şekilde ortaya konmuştur. Bir başka önemli tespitimiz ise Saliha Sultan'ın ilk evliliğini yaptığı Sarı Mustafa Paşa'nın Deli Hüseyin Paşa'nın oğlu değil torunu olduğudur.

Vakıflarına dair ise; aslı ve zeyli mevcut yedi suret vakfiye, farklı bir sistematikte değerlendirilerek ele alınmıştır. Bu doğrultuda 1192/1778 tarihli vakfiyesindeki tekrar problemi çözülmüştür. Burada şu an tam olarak izah edemediğimiz bir husus; Kethüda Ali Bey'in son vakfiyeyi Saliha Sultan'ın bilgisi dâhilinde mi, yoksa ondan habersiz olarak mı tanzim ettirip ettirmediğidir. Bu konu dönemin Evkaf-1 Hümayun Mahkemesi Sicillerinin incelenmesi ile açıklığa kavuşturulabilir.

Saliha Sultan vakıflarının hayır şartları tamamıyla ihtiyaç duyulan camilerde vaaz ve irşat yapılması, bir kısım eğitim faaliyetlerinin yürütülmesi ve Kur'an okunması gibi alanlara hasredilmiştir. Bu yönü ile Osmanlı hanımları arasında tesis yapmayan, ancak yapılmış büyük tesislere destek olan bir sistematikte değerlendirilebilir. Belki de büyük camiiler için yapılan zikrettiğimiz şartlar vakfın bugüne kadar canlı kalmasını sağlamıştır. Saliha Sultan'ın böyle bir tasarrufta bulunması vakfın ebediliği ve ihtiyaca mebni inşa edilmesi şartının da yerine geldiğinin bariz göstergesidir.

Çalışma ile halen yönetimi ve akarları devam eden Saliha Sultan Vakıflarının 1738'den günümüze uzanan serencamı ortaya konularak, özellikle XIX. asırda vakıf arazileri üzerinde zorunlu veya zoraki müdahaleler ortaya çıkarılmıştır. Vakfın mantığı yukarıda izah ettiğimiz üzere başlangıçta farklı tesis edilse de soyundan olan mütevellilerin Osmanlı döneminde akar ve hayratı takip etmeleri, Cumhuriyet Dönemi sonrasında ise Vakıflar Genel Müdürlügü’nün vakfa sahip çıkması ile Saliha Sultan Vakfı varlığını günümüze kadar devam ettirmiştir. Bu yönü ile vakfın tevliyeti ve akarlarının bir kısmı devam ediyor olsa da özellikle akarlarının büyük bir kısmı değişik zaman ve tasfiyelerde özelliğini kaybetmiştir. Bundan sonraki süreçte en azından mümkün olan akarlarının geri kazandırılması için bir süreç başlatılmalıdır. 
Hakem Değerlendirmesi: Dış bağımsız.

Çıkar Çatışması: Yazarlar çıkar çatışması bildirmemiştir.

Finansal Destek: Yazarlar bu çalıșma için finansal destek almadığını beyan etmiștir.

Peer-review: Externally peer-reviewed.

Conflict of Interest: The authors have no conflict of interest to declare.

Grant Support: The authors declared that this study has received no financial support.

\section{Kaynakça/References}

\section{Arșiv Kaynakları}

İsam Şer’iyye Sicilleri Evkaf-ı Hümayun Müfettişliği Mahkemesi Sicilleri (EHMS)

Türkiye Cumhuriyeti Cumhurbaşkanlığı Devlet Arşivleri Başkanlığı Osmanlı Arşivi (BOA)

Ali Emiri Mustafa III (AE.SMST.III)

Bâb-1 Ali Evrak Odası (BEO)

Evkaf (EV)

Şura-yı Devlet (ŞD)

Topkapı Sarayı Müzesi Arşivi Belgeleri (TSMA.D)

Topkapı Sarayı Müzesi Arşivi Evrakı (TSMA.E)

Yıldız Resmi Maruzat (Y.A.RES)

Türkiye Cumhuriyeti Vakıflar Genel Müdürlüğü Arşivi (VGMA)

Defterler, 36/66, 736, 739, 741, 780, 1757, 1829, 1835, 1965, esas 120/1773, esas 787/336-337.

\section{Kaynak Eserler}

Afyoncu, Erhan - Uğur Demir, Turhan Sultan, Yeditepe Yayınevi, İstanbul 2015.

Ahmed Cevdet Paşa, Tarih-i Cevdet, I, haz. Nezihi Aykut, TTK Yayınları, Ankara 2018.

Ahmed Resmi Efendi, Hamiletü'l-Kübera, haz. Ahmet Nezihi Turan, Kitabevi Yay., İstanbul 2000.

Akyıldız, Ali, Haremin Padişahı Valide Sultan Harem 'de Hayat ve Teşkilat, Timaş Yayınları, İstanbul 2017. , Mümin ve Müsrif Bir Padişah Kızl: Refia Sultan, Kapı Yayınları, İstanbul 2015.

Alderson, A. D., Osmanlı Hanedanının Yapısı, Türkçesi Şefaettin Severcan, İz Yayıncılık, İstanbul 1998.

And, Metin, Kırkgün Kırk Gece, Osmanlı Düğü̈leri ve Şenlikleri Geçit Alayları, Yapı Kredi Yayınları, İstanbul 2020.

Argıt, Betül İpşirli, Rabia Gülnuş Emetullah Sultan (1640-1715), Kitap Yayınevi, İstanbul 2014.

Arslan, Mehmet, "Osmanlı Döneminde Padişah Çocuklarının Doğumları Münasebetiyle Yapılan Şenlikler ve Vilâdet-nâme-i Hadîce Sultan”, Osmanlı Edebiyat-Tarih-Kültür Makaleleri, İstanbul 2000, s. 491-526.

, Osmanlı Saray Düğ̈̈nleri ve Şenlikleri 6-7, Sarayburnu Kitaplı̆̆ı, Çamlıca Basım Yayın, İstanbul 2011. 
Aydın, M. Akif - Muhammed Hamidullah, "Köle”, DİA, XXVI, İstanbul 2002, s. 237-246. , "Mehir", DİA, XXVIII, İstanbul 2003, s. 389-391.

Aykan, Eylül- Zübeyde Güneş Yağcı, "XVIII. Yüzyılda Sultanların Boğaz Yaşamına Katkıları: Büyük Esma Sultan”, Geçmişten Günümüze Şehir ve Kadın, I, ed. Osman Köse, Samsun 2016, s. 697-710.

Başarır, Özlem, Osmanlı Hanedan Kızları ve Gelirleri (XVIII. Yüzyıl XIX. Yüzyılın İlk Çeyreği), Kriter Yay, İstanbul 2018.

Çakmak, Abdullah, “18 Yüzyılda Hayırsever Bir Padişah Kadını Vuslat Kadın’ın Medine ve İstanbul Vakıfları," Vakıflar Dergisi, say1 52, İstanbul 2019, s. 75-92.

Dumas, Juliette, Les perles de nacre du sultanat Les princesses ottomanes (mi-XVe-mi-XVIIIe siècle, École des Hautes Études dn Sciences Sociales École Doctorale d'hıstorre et Civilisatıons, Thèse de Doctorat Inédite, Paris 2013.

, "Duhterciğimiz Dünyaya Geldi. III. Ahmed'in ilk kız çocuğu Fatma Sultan doğumu şerefine düzenlenen şenlikler”, Toplumsal Tarih, sayı 198 (Haziran 2010), s. 22-28.

Güler, Mustafa, "Hatipzade Yahya Paşanın Rumeli'deki Eğitim ve İmar Faaliyetleri”, III. Balkanlarda İslam Medeniyeti Sempozyumu Tebliğler Kitab1, 2006, s. 413-420.

, "Eyüplü Yahya Paşa ve İstanbul'daki Eserleri”, VIII. Eyüp Sultan Sempozyumu Tebliğler, 2004, s. 40-43.

Hammer-Purgstall, Joseph Freiherr von, Büyük Osmanlı Tarihi, XIV-XVI, yay. haz. Erol Kılıç - Mümin Çevik, Üçdal Neşriyat, İstanbul 1994.

İzzî Süleyman Efendi, İzî Tarihi, haz. Ziya Yılmazer, Türkiye Yazma Eserler Kurumu, İstanbul 2019.

Kaya, Münir, "Fıłkî Açıdan Aile İçerisinde Yapılan Mülkiyet Nakilleri ve Aile Vakfiyla İlişkisi”, Afyon Kocatepe Üniversitesi Íslami İlimler Fakültesi Dergisi, III/1 (Haziran 2020), 53-93.

Kut, Günay - Nimet Bayraktar, Yazma Eserlerde Vakıf Mühürleri, Kültür Turizm Bak. Yayınları, Ankara 1984.

Maydaer, Saadet, “Osmanlı Toplumunda Vakıf Kuran Kadınlar ve Mal Varlıklarının Kaynakları”, Vakıf Kuran Kadınlar Sempozyumu Tebliğleri, Ankara 2019, s. 143-158.

Mehmed Hâkim Efendi, Hâkim Efendi Tarihi, haz. Tahir Güngör, I, Türkiye Yazma Eserler Kurumu, İstanbul 2019.

Mehmed Râşid, Tarih-i Râşid, IV, İstanbul 1282.

Mehmed Süreyya, Sicill-i Osmânî Yahud Tezkire-i Meşahir-i Osmaniyye, I, haz. Ali Aktan vd., Sebil Yayınevi, İstanbul 1995.

Osmanlıca Tıp Terimleri Sözlüğ̈̈, haz. Ekrem Kadri Unat-Ekmeleddin İhsanoğlu-Suat Varol, Ankara 2004.

Öztürk, Nazif, Türk Yenileşme Tarihi Çerçevesinde Vakıf Müessesesi, TDV Yayınları, Ankara 1995.

Sağır, Yusuf, “Gâzî Hüseyin Paşa’nın Girit’teki Vakıf Eserleri”, Turkish Studies, VIII/2 (Kış 2013), s. 285301.

Sakaoğlu, Necdet, Bu Mülkün Kadın Sultanlarl, Alfa Yayınları, İstanbul 2015.

Subhi Mehmet Efendi, Subhi Tarihi: Sami ve Şakir Tarihleri ile Birlikte 1730-1744 (inceleme ve karşılaştırma metin), haz. Mesut Aydıner, Kitabevi Yayınları, İstanbul 2007.

Sunay, Serap, “Bir Sultan İki Merasim: Saliha Sultan’ın Doğumu ve Dügünü”, Türk Kültürü Incelemeleri Dergisi, XXI/44 (2020), s. 139-182. 
, “Tanzimat'ın İlk Saray Düğünü: Sultan II. Mahmud'un Kızı Atiyye Sultan'ın Ahmed Fethi Paşa ile Evlenmesi”, Belleten, LXXVII/278 (Nisan 2013), s. 119-154.

Şemdanizâde Fındıklılı Süleyman Efendi, Müri 't-tevârih, haz. M. Münir Aktepe, İÜ. Edebiyat Fak. Yayınları, İstanbul 1978.

Şemseddin Sami, Kâmûs-ı Türkî, İdeal Kültür ve Yayıncılık, İstanbul 2011.

Terzi, Arzu, Bezmialem Valide Sultan, Timaş Yayınları, İstanbul 2018.

Tezcan, Hülya, Osmanlı Sarayının Çocukları, Aygaz Yayınları, İstanbul 2006.

Uluçay, Çağatay, “İstanbul'da XVIII. ve XIX. Asırlarda Sultanların Doğumlarında Yapılan Törenler ve Şenliklere Dair”, İstanbul Enstitüsü Mecmuası, say1 4, İstanbul 1958, s. 199-213. , Padişahların Kadınları ve Kızları, TTK Yayınevi, İstanbul 1985. , Harem II, Türk Tarih Kurumu Basımevi, Ankara 1992.

Yağcı, Zübeyde Güneş - Mustafa Akkaya, III. Murad ve Safiye Sultan'ın Kızları Ayşe Sultan, Berikan Yayınları, Ankara 2018.

\section{İnternet}

http://www.esenler.gov.tr/tarihce (erişim tarihi 8.6.2021).

https://kulturenvanteri.com/yer/ayastefanos-rus-abidesi/\#16.59/40.983434/28.788457 (erişim tarihi 26.6.2021). https://www.turkyurdu.com.tr/yazar-yazi.php?id=3770 (erişim tarihi 26.6.2021)

https://www.vgm.gov.tr/kurumsal/tarihce/vakif-deyimleri-ve-terimleri-sozlugu erişim tarihi, 4.10.2021. 


\section{Ekler}

Ek 1- Saliha Sultan Vakıf Akarları Haritas1

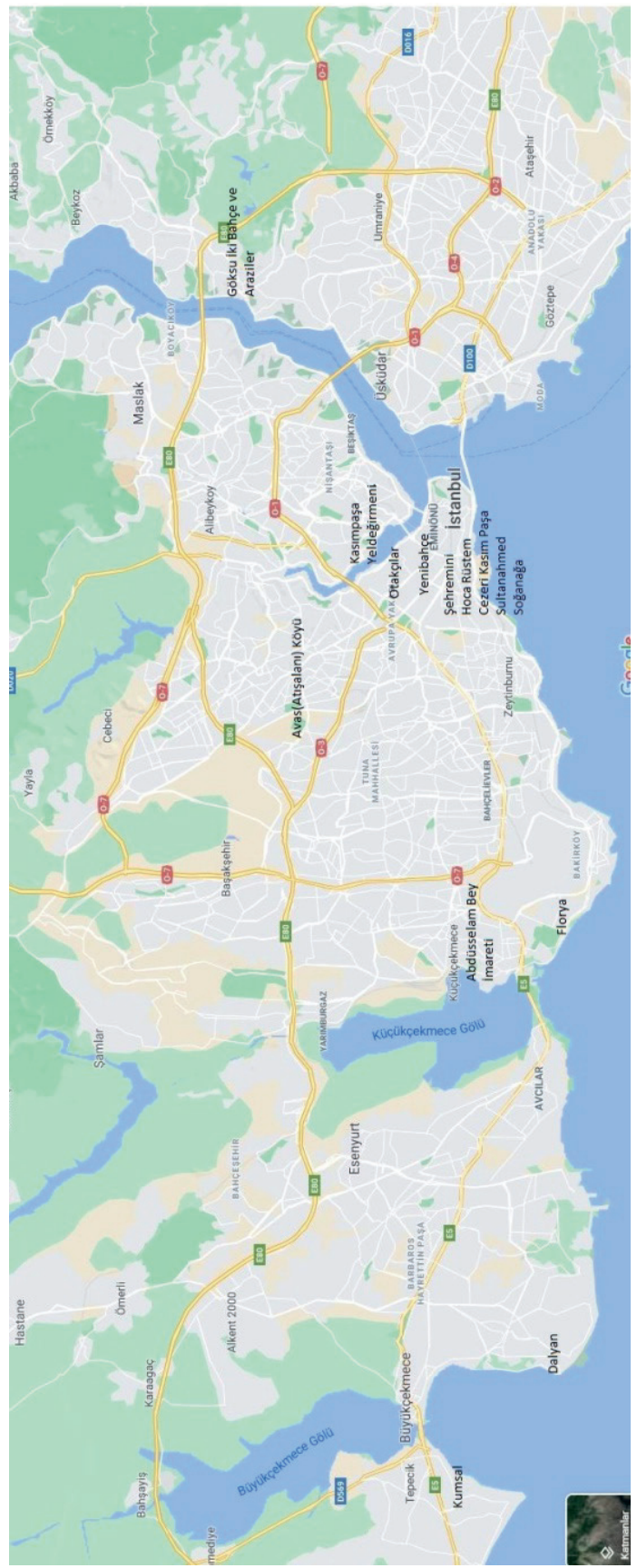


Ek 2- Saliha Sultan’ın İlk Tanzim Ettirdiği 1151/1738 Tarihli Vakfiyenin Birinci Sahifesi (VGMA, 736, s. 77, sira 27/1)

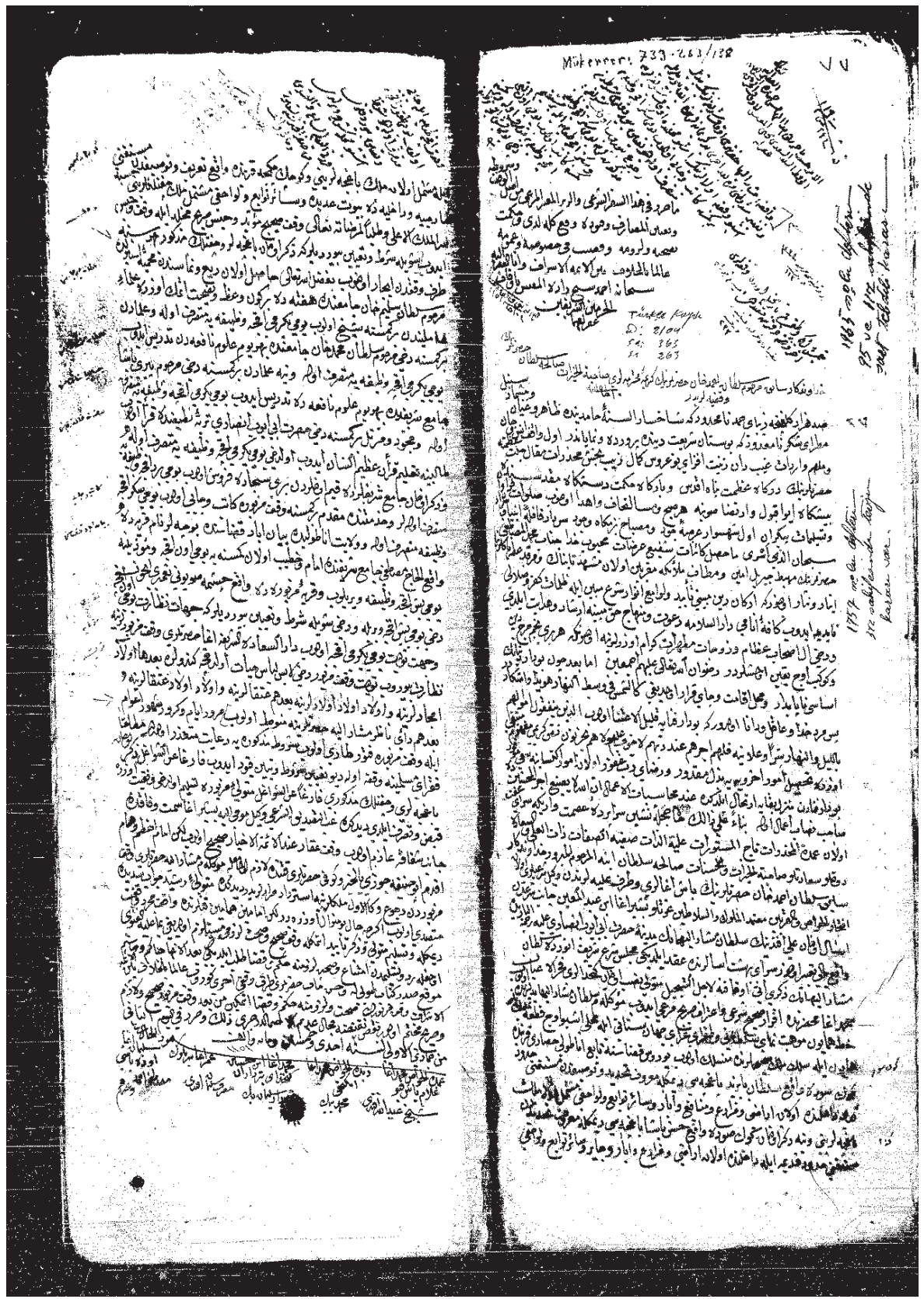


Ek 3- Vakfin 1329 Tarihli Muhasebesi

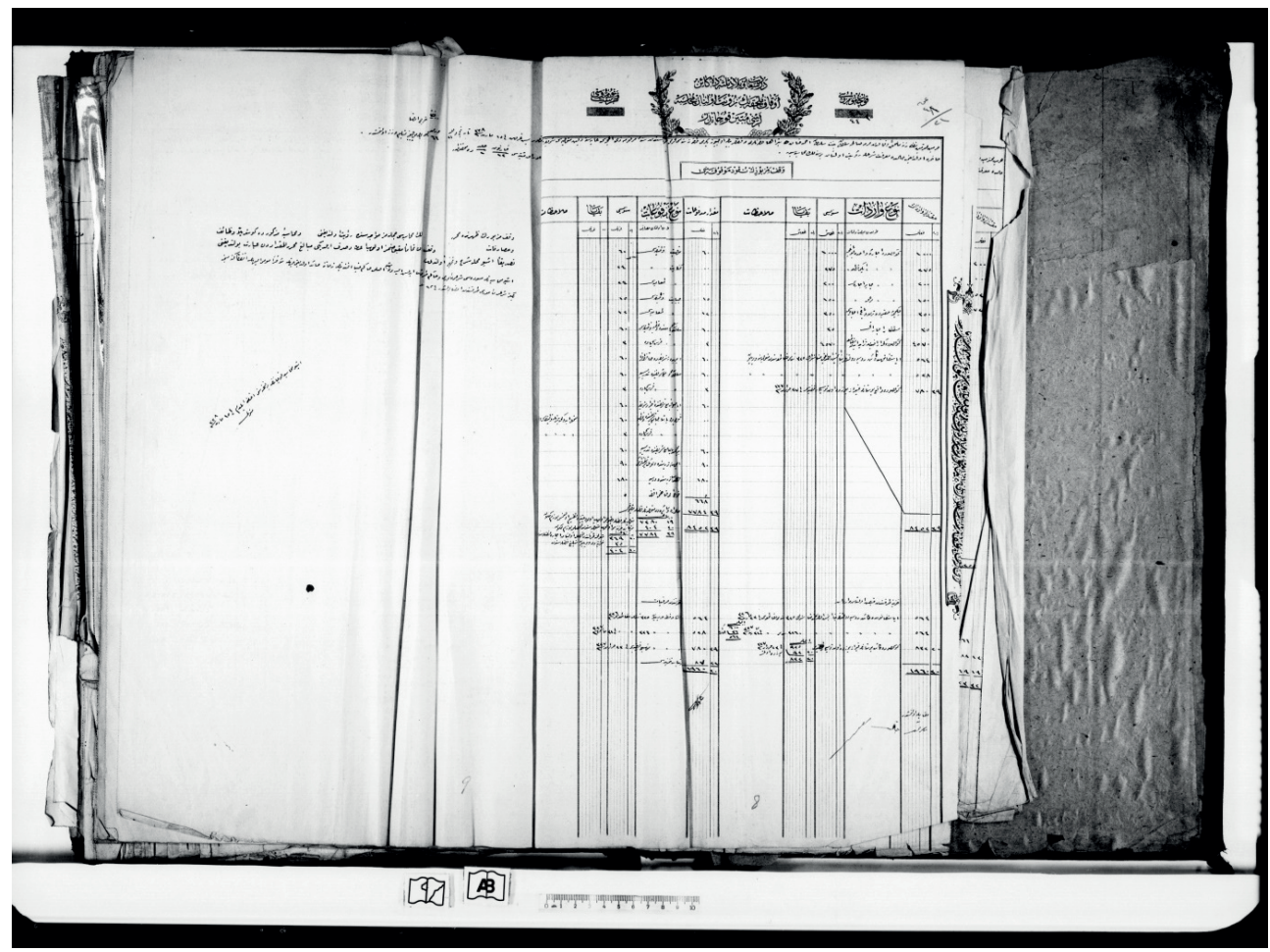


Ek 4- Saliha Sultan Vakıfları Muhasebe Defteri $(\mathrm{EV}, 38215,1 \mathrm{~b})$

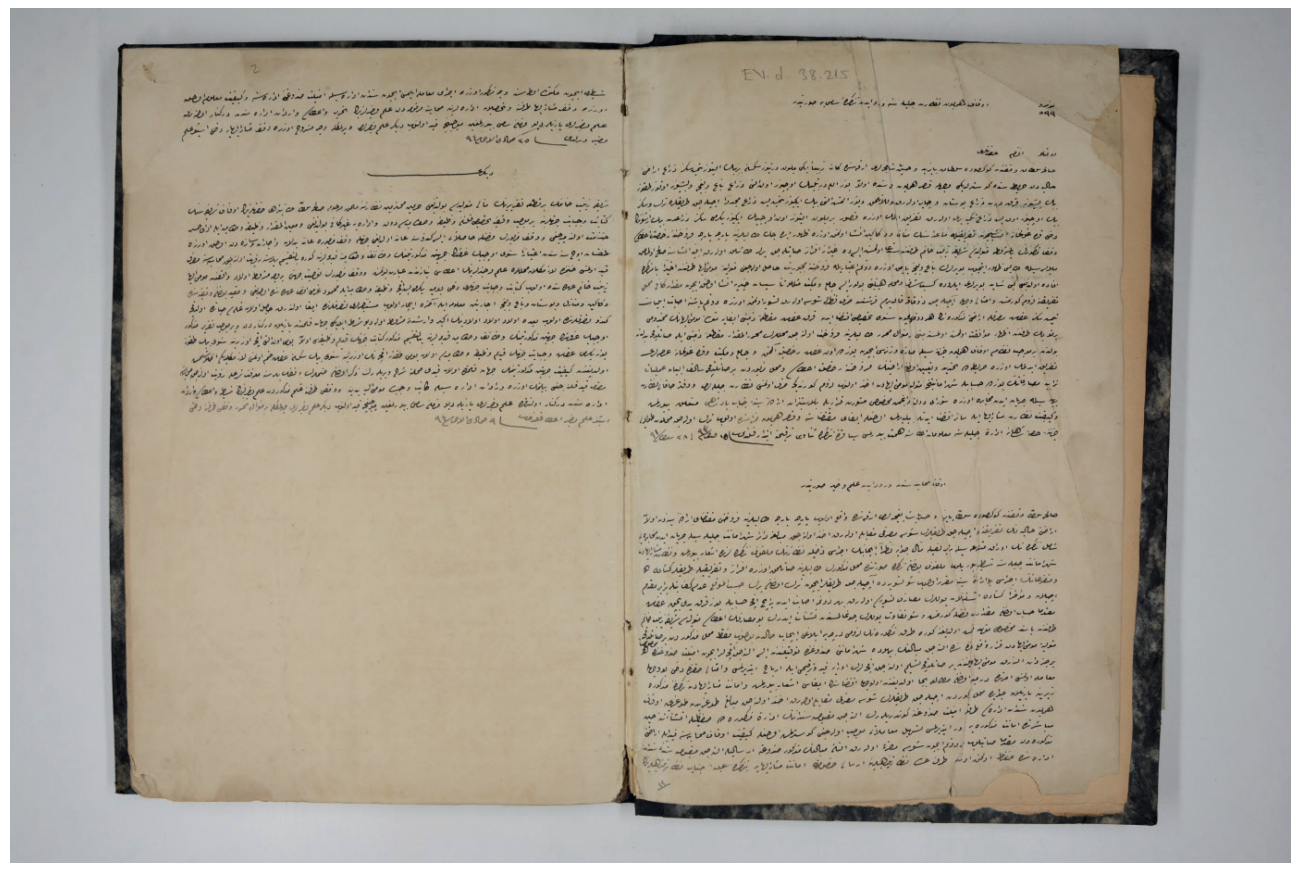


Ek 5- Göksu'daki Arazilerin Temliknamesi (YA.RES, 148/27-5-1)

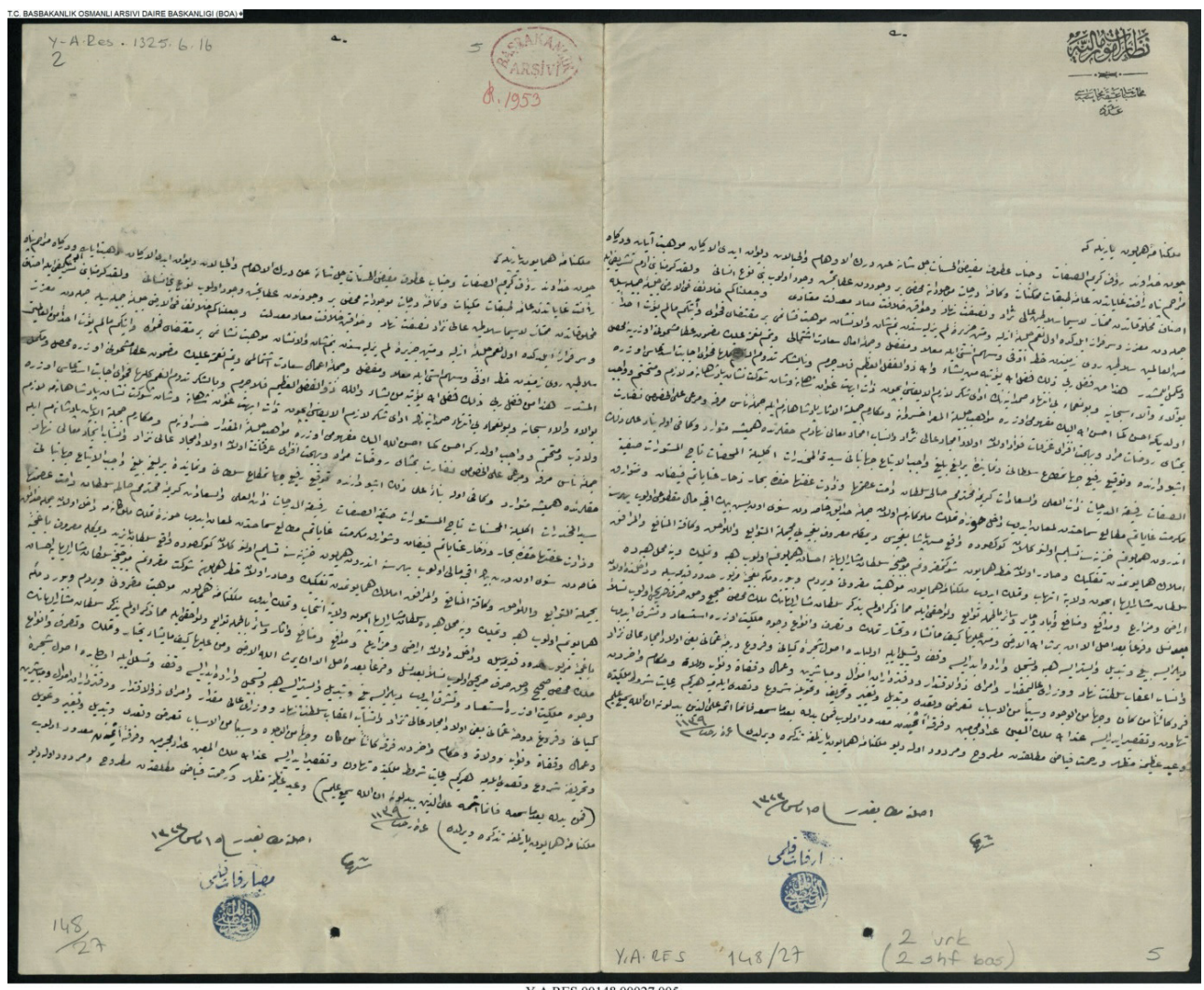

YARES.00148.00027.005 
Ek 6- Saliha Sultan'ın El Yazısı ile Sultan I. Mahmud'a Yazdığı Tebrikname (TSMA, E.201/31-3-1)

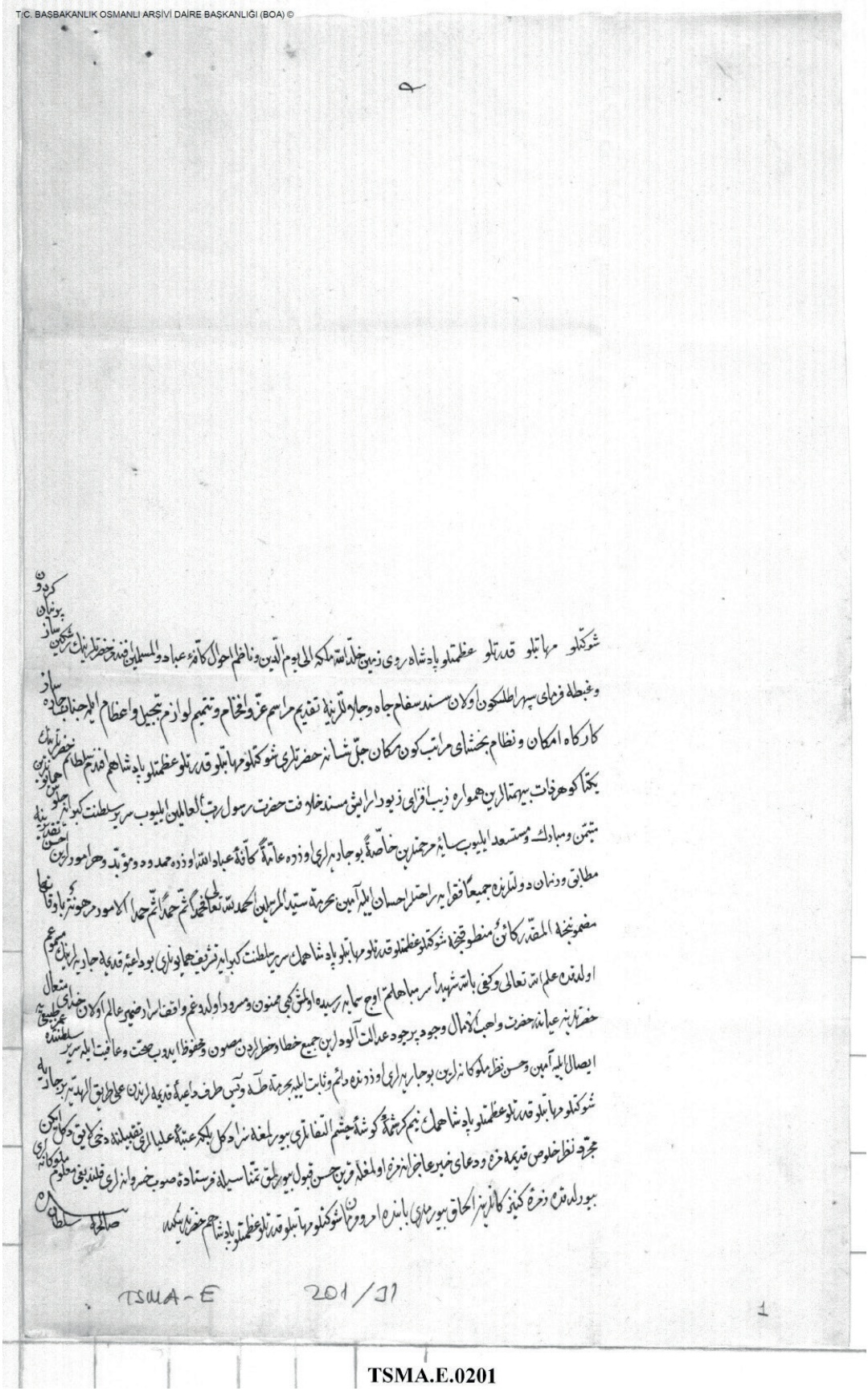

